\title{
Structural and Functional Insights into the Role of Guard Cell Ion Channels in Abiotic Stress-Induced Stomatal Closure
}

\author{
Hamdy Kashtoh and Kwang-Hyun Baek* \\ Department of Biotechnology, Yeungnam University, Gyeongsan 38541, Gyeongbuk, Korea; \\ hamdy_kashtoh@ynu.ac.kr \\ * Correspondence: khbaek@ynu.ac.kr; Tel.: +82-53-810-3029
}

Citation: Kashtoh, H.; Baek, K.-H. Structural and Functional Insights into the Role of Guard Cell Ion Channels in Abiotic Stress-Induced Stomatal Closure. Plants 2021, 10, 2774. https://doi.org/10.3390/ plants10122774

Academic Editor: Francisco Javier Cano Martin

Received: 24 October 2021

Accepted: 7 December 2021

Published: 15 December 2021

Publisher's Note: MDPI stays neutral with regard to jurisdictional claims in published maps and institutional affiliations.

Copyright: (c) 2021 by the authors. Licensee MDPI, Basel, Switzerland. This article is an open access article distributed under the terms and conditions of the Creative Commons Attribution (CC BY) license (https:/ / creativecommons.org/licenses/by/ $4.0 /)$.

\begin{abstract}
A stomatal pore is formed by a pair of specialized guard cells and serves as a major gateway for water transpiration and atmospheric $\mathrm{CO}_{2}$ influx for photosynthesis in plants. These pores must be tightly controlled, as inadequate $\mathrm{CO}_{2}$ intake and excessive water loss are devastating for plants. When the plants are exposed to extreme weather conditions such as high $\mathrm{CO}_{2}$ levels, $\mathrm{O}_{3}$, low air humidity, and drought, the turgor pressure of the guard cells exhibits an appropriate response against these stresses, which leads to stomatal closure. This phenomenon involves a complex network of ion channels and their regulation. It is well-established that the turgor pressure of guard cells is regulated by ions transportation across the membrane, such as anions and potassium ions. In this review, the guard cell ion channels are discussed, highlighting the structure and functions of key ion channels; the SLAC1 anion channel and KAT1 potassium channel, and their regulatory components, emphasizing their significance in guard cell response to various stimuli.
\end{abstract}

Keywords: guard cell; abiotic stress; KAT1; SLAC/SLAH; abscisic acid signaling; kinases

\section{Introduction}

Plants must adapt to different environmental challenges such as drought, elevated $\mathrm{CO}_{2}$ and $\mathrm{O}_{3}$, and pathogen attacks to survive. The guard cell plays an essential role in plants when adapting to such environmental stimuli, which are on the rise due to global warming. It is comprised of two kidney-shaped cells forming a stomatal pore in the plant leaf epidermis and is responsible for gaseous exchange between the plants and the surrounding environment [1-5]. Stomata opening is induced by light, allowing a $\mathrm{CO}_{2}$ influx during photosynthesis in the leaves, whereas stomata pore closure occurs when plants are exposed to water-deprived conditions to keep the water balance in plants maintained. Stomata movements are achieved via ion fluxes to control guard cell turgor pressure in response to environmental stimuli with a highly sophisticated signaling network that controls cation and anion channels located in the PM (plasma membrane) and tonoplast of the guard cell and is responsible for tuning the stomatal movement. Light-induced stomatal opening is governed by $\mathrm{K}^{+}$in (inward-rectifying potassium) channels present in the PM of the guard cells, such as KAT1, KAT2, AKT1, and AKT2. In Arabidopsis thaliana, KAT1 and KAT2 channel activity represents a major contributor to a potassium influx in the guard cell [6-13]. On the other hand, stomatal closure requires a coordinated efflux of anions and potassium ions from the guard cell via anion channels such as S-type slow activated anion channels (S-type), R-type rapidly activated anion channels (R-type), and $\mathrm{K}^{+}$out outward-rectifying potassium $\left(\mathrm{K}^{+}\right.$out $)$channels [14-26]. It has been proposed that the activation of the S-type anion channel SLAC1 in the guard cells is a key event leading to the closing of stomata pores $[17,18,27]$. Abscisic acid (ABA) regulates the cellular activities that coordinate anion effluxes, inhibits $\mathrm{K}^{+}$in channels, and activates $\mathrm{K}^{+}$out channels in a signaling pathway mediated by ABA receptors, phosphatases/kinases, and ion channels. Upon environmental stimuli such as drought, ABA production in the guard cell increases and elevates cytosolic calcium concentrations, initiating a cascade of signaling events, 
thereby leading to ion effluxes outside the guard cell, reducing the turgor pressure and stomata closure which occurs to maintain water balance in plants [28-31]. There are several intertwined signaling pathways in the guard cell that regulate ion channel activity and modulate stomatal movements in response to environmental stimuli. For instance, under abiotic stress, ABA and $\mathrm{H}_{2} \mathrm{O}_{2}$ (reactive oxygen species (ROS)) levels increase which triggers an elevated cytosolic calcium concentration that in turn activates the calcium protein kinases which regulates ion channel activities and tolerates such abiotic stress [32-34]. Several other signaling cascades that regulate stomatal movements are generated in response to stress, such as plant hormones brassinosteroid (BR) signaling which helps plants tolerate stress environments [35-37]. Our knowledge about the functions and regulation of the ion channels in stomatal movement comes from electrophysiological studies conducted on single guard cells and the analysis of the effects of the ion channel mutants on the stomatal operation. Slow anion channel associated-1 (SLAC1) was discovered during the genetic screening for $\mathrm{O}_{3}$ or $\mathrm{CO}_{2}$ sensitivity in Arabidopsis. When the SLAC1 channel was mutated, the resulting plants no longer responded to $\mathrm{O}_{3}$ stress and elevated $\mathrm{CO}_{2}$ whereas a slow modest response was observed when light and air humidity were changed $[17,18]$. Integration of these techniques and proteomics helped elucidate signaling mechanisms contributing to guard cell movement. Insights into these mechanisms will help breed plant crops with better water tolerance. In this review, we highlight the recent progress in the signaling networks that coordinates the activation and inhibition of ion fluxes of potassium and anions such as chloride, nitrate, and malate during stomatal closure. Moreover, the structure and function of the key channels SLAC1 and KAT1 that are involved in guard cell stomatal movement are discussed.

\section{Guard Cell Potassium Channels}

There are fifteen potassium channels identified in Arabidopsis thaliana; nine Shaker channels and six TPKs two-pore $\mathrm{K}^{+}$channels (TPKs) $[38,39]$. Shaker family potassium channels are best characterized and they mediate the potassium fluxes at the plasma membrane. The members of the shaker family can be classified into two categories: (i) inward rectifying channels, which include KAT1, KAT2, AKT1, AKT2, AKT6, SPIK, and AtKC1, and (ii) outward rectifying channels that include GORK and SKOR $[13,40,41]$. Six of the shaker family members are expressed in the guard cells and have a significant role in the stomatal opening (KAT1, KAT2, AKT1, AKT2, and AtKC1) and closing (GORK) [9,13,42]. A complex array of signaling cascades will lead to the activation of $\mathrm{K}^{+}$in channels. Light and other pathways such as binding of $14-3-3$ protein, $\mathrm{Ca}^{2+}$ elevation, $\mathrm{K}^{+}$influx, and ABA-induced $\mathrm{H}_{2} \mathrm{O}_{2}$ activity mediate stomatal movement by regulating $\mathrm{PM} \mathrm{H}^{+}$-ATPase activity [43-49]. The $\mathrm{PM} \mathrm{H}^{+}$-ATPase receives the blue light-activated signal, which causes phosphorylation of the $\mathrm{H}^{+}$-ATPase C-terminus [44]. When activated by blue light and Fusicoccin, the 14-3-3 protein binds to the $\mathrm{PM} \mathrm{H}^{+}$-ATPase, which raises the negative electrical potential gradient inside the $\mathrm{PM}$ and drives $\mathrm{K}^{+}$in channels $[44,47]$. As a result, the uptake of potassium ions leads to an increase in the turgor pressure of the guard cell, ensuing stomatal opening $[12,50,51]$. On the other hand, when $\mathrm{K}^{+}$out channels are activated, potassium ions and anions are released along with water effluents. Subsequently, guard cell turgor pressure decreases leading to stomatal closure [52,53].

Shaker channels are composed of four alpha subunits that can be assembled from identical shaker genes, forming homomeric channels, or from different shaker genes, generating heteromeric channels, which is more preferable in Arabidopsis thaliana to increase functional diversity [54-56]. The tetramers are orderly positioned surrounding a central pore, which is selective for potassium ions. Each alpha subunit is comprised of six transmembrane (TM) segments forming the hydrophobic core with a potassium selectivity filter and cytosolic $\mathrm{N}$-and C-termini. The pore loop domain (P domain) membrane links the fifth and the sixth TM segments forming the walls of the channel pore. The $\mathrm{P}$ domain comprises highly conserved residues (threonine-valine/threonine-glycine-tyrosine-glycine) at the narrowest area of the pore and serves as a selectivity filter. Positively charged amino acids (lysine or 
arginine) are present at the fourth TM segment, which controls the shaker channel gating by voltage; the changes in TM electrical potential cause this segment to move within the membrane, resulting in conformational changes in the channel and consequently leading to the opening or closure of the channel pore. Shaker channels have a rather large C-terminus that contains multiple domains comprising a cyclic-nucleotide binding site in addition to an ankyrin repeat domain responsible for interaction with regulatory proteins, and an acidic (KHA) C-terminal end [11,57-61].

KAT1 is considered a major $\mathrm{K}^{+}$in channel in the guard cell that has a dominant role in stomatal opening $[7,9,62]$. Interestingly, a recent publication reports that the Shaker-type channel KDM1 in Dionaea muscipula, which represents an ortholog of the Arabidopsis thaliana KAT1, was not expressed in D. muscipula guard cells. It thus implies that stomatal opening in D. muscipula is independent of KDM1, though further experiments are needed to prove this concept [63]. KAT1 and KAT2 are expressed in the guard cell with a higher level than other $\mathrm{K}^{+}$in such as AKT1 and AKT2. Although KAT1 is considered a dominant $\mathrm{K}^{+}$in channel in the guard cell, the stomatal opening is still observed when it is knocked out and that may be due to KAT2, AKT1, and AKT2 subunits that can compensate for KAT1 loss $[6,8,9]$. Recently, the structure of the Arabidopsis KAT1 potassium channel was revealed. The KAT1 structure comprises a tetramer channel where each protomer contains four TMs (helices S1-4) known as a voltage sensor domain (VSD) and two TMs (helices S5, S6) of the pore domain (helices S5, S6). The helix S6 bends sharply at its C terminus, generating the C-linker helix-turn-helix motif followed by an intracellular polypeptide chain, generating the cyclic nucleotide-binding domain (CNBD). The study shows that an inbound movement of the S4 sensor helix of about 5-7 $\AA$ can cause an interaction between the sensor segment and the C-linker, resulting in changes in the conformation of the C-linker and eventually opening the activation gate formed by the S6 via a direct coupling mechanism (Figure 1) [64,65].
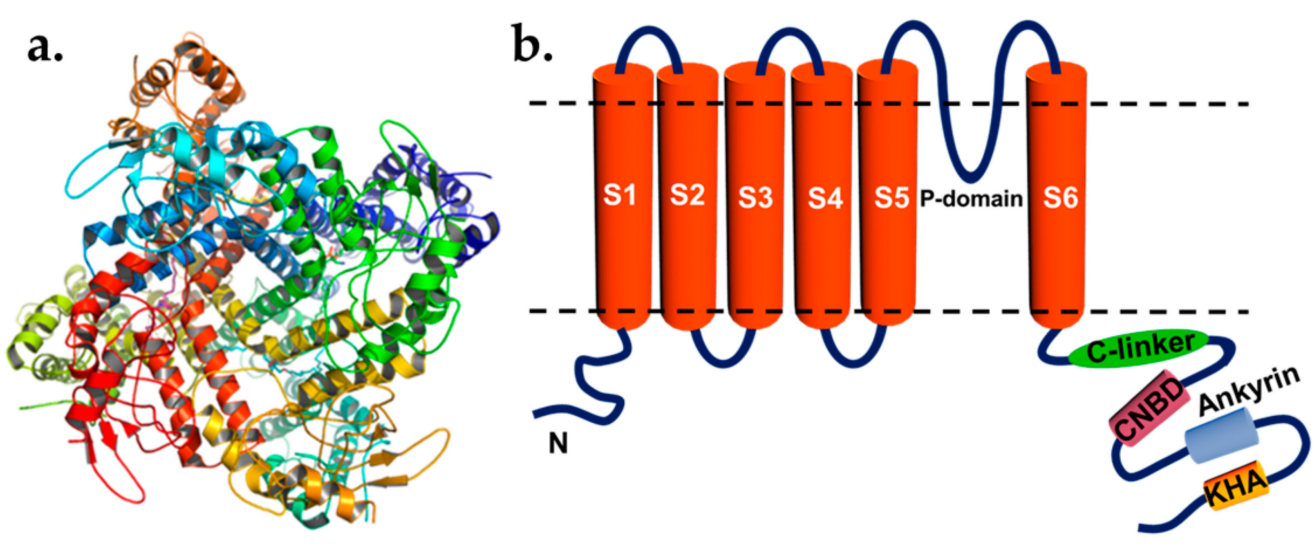

Figure 1. (a) Ribbon diagram of the structure of the Arabidopsis thaliana $\mathrm{K}^{+}$in KAT1 tetramer (top view). (b) Topology of KAT1 subunit based on its structural model. (a) Was adopted from the structure, PDB entry code: 7CAL [65], and generated using PyMol [66].

\section{Guard Cell Anion Channels}

In the 1980s, patch-clamp studies showed that anion channels in the guard cell can be distinguished into two types: Slow (S)-type and rapid (R)-type [67]. As the name implies, the R-type channel activates swiftly by depolarization, while the S-type channel activates slowly in a voltage-dependent manner [67-70]. Almost three decades later, a mutational analysis on Arabidopsis revealed that an ozone-sensitive mutant, with high stomatal conductance, lacks the activity of S-type guard cell anion channels by calcium or ABA. This mutant was therefore called SLAC1, and the SLAC1 gene encodes an S-type anion channel in the guard cell $[17,18]$. In Arabidopsis, SLAC1 is considered the founder of a gene family that contains SLAC1 and four of its homologue genes (SLAH1-4). The phylogenetic tree of the SLAC1 family has two branches, with SLAC1, SLAH2, and SLAH3 on one branch and SLAH1 and SLAH4 on the other [71] (Figure 2a). SLAC1, SLAH2, 
and SLAH 3 have cytoplasmic N and C-termini, while SLAH1 and SLAH4 have a very short $\mathrm{N}$-terminus and a shorter $\mathrm{C}$-terminus compared with the other family members (Figure 2b). SLAC1 and its homologue SLAH3 are expressed in the guard cell and are essential for stomatal closure [24,72]. A recent study using the optogenetic approach showed that the activation of the light-gated anion channel rhodopsin 1 (GtACR1) in tobacco guard cells was sufficient to close stomata [27]. This finding provides strong evidence that anion channels activation, such as SLAC1, is sufficient for stomatal closure. Although SLAC1 and SLAH3 activity led to stomatal closure, SLAH3 possesses some unique features. For instance, SLAC1 is permeable to nitrate and chloride, though, SLAH3 chloride/nitrate permeability is low [24]. However, SLAH3 chloride/nitrate permeability increased when SLAH1/SLAH3 are co-expressed in Xenopus oocytes which enabled the formation of a heterodimer [73]. Furthermore, unlike SLAC1, SLAH3 needed a rise in extracellular nitrate concentrations for complete channel activation [24,73,74]. Nevertheless, both anion channels share activation by most of the calcium-dependent kinases $[24,74,75]$. A recent study showed that under microbial immune response in plants, the activation of SLAH3 by a receptor-like cytoplasmic kinase PBL27 contributes to stomatal closure [76]. Another interesting study showed that in Arabidopsis thaliana roots, the SLAH3 anion channel is activated under flooding stress due to the acidification of the cytosolic $\mathrm{pH}$ and thus it was proposed that SLAH3 might act as a pH sensor to start the flooding stress complex signal response via membrane depolarization [77]. SLAH1 is expressed in the root and plays a role in modulating chloride ion root to shoot transport [78]. SLAH2 is a nitrate-specific anion channel localized in plant roots that is impermeable to chloride ions. When a point mutation is introduced, SLAH2 turns into a nitrate/chloride anion channel [79]. During drought, a signaling cascade causes the activation of the SLAC1 anion channel via phosphorylation and stomatal closure. Upon phosphorylation, SLAC1 releases anions (e.g., $\mathrm{Cl}^{-}$and $\mathrm{NO}_{3}{ }^{-}$) from the guard cells and depolarizes membrane potential, leading to the activation of $\mathrm{K}^{+}{ }_{\text {out }}$. Activated $\mathrm{K}^{+}$out releases potassium ions along with water from the cell, thereby decreasing guard cell turgor pressure and closing down the stomatal pore.

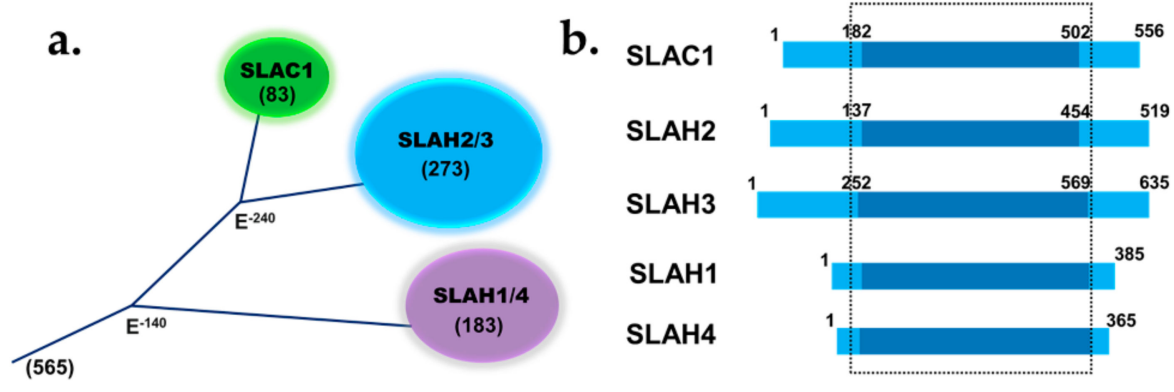

Figure 2. (a) The phylogenetic tree of the SLAC1 protein family. (b) SLAC1 family diagram based on sequence alignment shows SLAH1 and SLAH4 have a short N-terminus and a shorter C-terminus compared with the other family members. The $\mathrm{N}$ and C-termini are colored blue and the TM domains are colored navy blue.

Recently, the cryo-EM structure of the BdSLAC1 (SLAC1 anion channel from Brachypodium distachyon) was revealed [80]. The structure showed that BdSLAC1 is a symmetric trimer and has a positive electrostatic potential surface on both the extracellular and cytoplasmic sides (Figure 3a). Each SLAC1 protomer has ten TM helices, arranged as five pairs of helical hairpins that are assembled into a unique protein fold with quasi-five-fold symmetry. $\mathrm{TM}_{\text {odd }}$ helices form a channel pore across the membrane, which is blocked by a highly conserved two phenylalanine residue-motif (F460 and F285 in BdSLAC1/F450 and F276 in AtSLAC1 (Arabidopsis thaliana SLAC1)). TMeven helices are straight and elongated but more inclined surrounding the inner pore while forming an external layer at the same time (Figure 3b,c). 


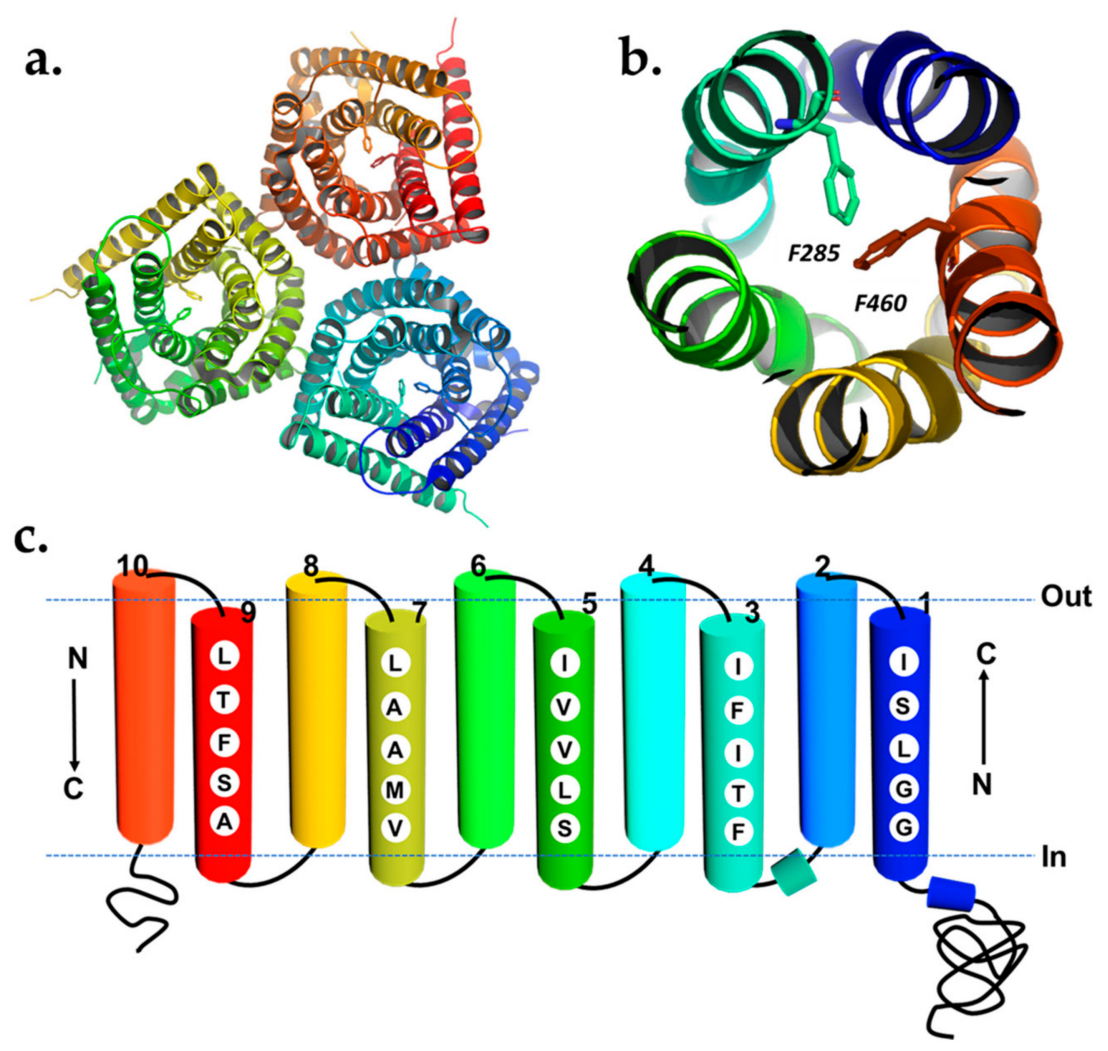

Figure 3. (a) The ribbon diagram of a BdSLAC1 trimer (top view) colored spectrally. (b) BdSLAC1 monomer is colored spectrally (top view) and the phenylalanine gating residues (F460 and F285) are shown in stick bonds within the channel pore. The pore-forming $\mathrm{TM}_{\mathrm{odd}}$ helices are shown as a ribbon with $\mathrm{TM}_{\text {even }}$ removed. (c) Topology of SLAC1 subunit based on its structural model. Pore-lining residues are indicated in $\mathrm{TM}_{\text {odd }}$ helices of the BdSLAC1 rolled-open model. $(\mathbf{a}, \mathbf{b})$ Were adopted from the structure, PDB entry code: 7EN0 [80], and generated using PyMol [66].

SLAC1 has a unique structure and distinctive mechanism for gating. Dual high-energy phenyl rings of two conserved pore-lining phenylalanine residues interact and occlude the channel pore, and the channel vibrates between open and closed conformation. A recent study showed that there are six phosphorylation sites at the SLAC1 cytosolic N-terminus which can be phosphorylated by OST1 (Open stomata 1) kinase [80]. These multiple phosphorylation sites may act as a platform for other kinases to fine-tune and modulate SLAC1 activities. Highly conserved, positively charged residues on the cytoplasmic side provide potential interacting sites for the phosphorylated serine/threonine upon kinase activation. This interaction prompts the twisting of the pore-forming helices to unlatch the high-energy gate from occluding the pore as shown in Figure $3[80,81]$.

In Arabidopsis thaliana, ALMT12 (also referred to as QUAC1; quick-activating anion channel 1) of the aluminum-activated malate transporter (ALMT) family, is predominately expressed in the guard cell and identified as the major component related to the R-type anion channel [16]. In response to several stimuli such as $\mathrm{ABA}$, calcium, and $\mathrm{CO}_{2}$, stomatal closure was partly defective in atalmt12 mutant plants $[16,26,82]$. This finding suggests that the guard cells might have other unidentified members of the R-type channels (QUACs). ALMT12 is permeable to malate, nitrate, and chloride ions and is activated through depolarization and inactivated by hyperpolarization rather than kinases [83]. Unlike AtALMT1, the activity of AtALMT12 is not governed by $\mathrm{Al}^{3+}[16,84]$. Recently, the structural basis of the ALMT12 channel was revealed to be a symmetrical dimer that forms a pore with a T-shape which is responsible for passing anions across the membrane [85]. The ALMT12 structure is composed of two layers that can be divided into the TM and $\mathrm{CH}$ (cytoplasmic helical) domains. The TM domain consists of $6 \mathrm{~V}$-shaped TM helices and the $\mathrm{CH}$ domain comprises 
7 helices. Interestingly, there is a region in the $\mathrm{CH}$ domain enriched with serine/threonine residues that may contain a phosphorylation site for ALMT12 regulation [85].

In the guard cell tonoplast, there are three members of the ALMT family; AtALMT4, 6, and 9 [71,86-89]. AtALMT6 can mediate malate and fumarate fluxes depending on the tonoplast polarization state; upon tonoplast depolarization, a malate efflux occurs, while a malate influx occurs upon hyperpolarization. AtALMT6 is a $\mathrm{Ca}^{2+}$-activated channel and its activity is modulated by vacuole $\mathrm{p}^{\mathrm{H}}$. Atalmt 6 mutant plants exhibited almost no phenotypic differences; however, the malate currents were reduced in the guard cell vacuole compared with wild-type plants [86]. Ye et al. showed that ALMT6 is involved in stomatal opening and the stomata opening was defective in ALMT6 in response to blue light [90]. On the other hand, AtALMT9 is activated by cytosolic malate and acts as a chloride efflux channel. An atalmt9 mutant revealed that AtALMT9 plays a role in stomatal opening [87]. Another member of the tonoplast ALMT family member is AtALMT4, which can mediate anion fluxes in a phosphorylation-dependent manner. The study demonstrated the assembly of AtALMT4 in ABA-triggered stomatal closure. Atalmt4 mutant plants exhibited impairment during ABA-triggered stomatal closure [91]. Malate influx through the guard cell PM is mediated by an ABC transporter (i.e., AtABCB14), and involved in stomatal opening [92]. Recently, a study showed that cytosolic malate can regulate stomatal movement in Arabidopsis via the indirect activation of S-type anion channels and such activity was abolished in OST1 and cpk5/6/11/23 quadruple mutant guard cells [93]. The above-mentioned ALMTs illustrate the significant role of malate during stomatal movement.

\section{Guard Cell Signaling Elements Involved in Stress-Induced Stomatal Closure}

ABA plays a main role in controlling stomatal closure via the activation of a complex signaling cascade that is mediated by different signaling elements including ABA receptors, kinase/phosphatases, and ion channels [94-96]. There are three kinase families involved in signaling pathways related to drought, osmotic stress, salt stress, and potassium deficiency [97-99]; the Sucrose Non-Fermenting 1 (SNF1) related protein Kinase-2 (SnRK2) family [100], the calcium-dependent protein kinase (CDPK/CPK) family [101], and the SnRK3 family (SNF1-related protein kinase 3)or CIPK; calcineurin B-like-interacting protein kinase [102]. In Arabidopsis, there are ten SnRK2s, among them, OST1/SnRK2.6 is a key regulator of the ABA-dependent stomatal closure [100]. OST1 is an ABA-dependent, calcium-independent protein kinase, whereas CPKs and CIPKs are calcium-dependent protein kinases that rely on calcium for their activity $[102,103]$. There are $34 \mathrm{CPK}, 26 \mathrm{CIPK}$, and 10 CBLs members in Arabidopsis; CBL acts as a calcium sensor, not as a kinase. After calcium binding, CBL is activated and interacts with a kinase family CIPK leading to CIPK autophosphorylation and regulation of downstream target proteins including transcriptional factors, NADPH oxidases, transporters, and ion channels [104-108]. CIPKs are comprised of a kinase domain, an autoinhibitory (NAF/FISL) domain, and a phosphatasebinding domain (protein phosphatase interaction (PPI)). CIPK auto-inhibition is eliminated when the calcium-dependent CBL interacts with the NAF domain of CIPK [109]. As for $\mathrm{CPKs}$, they have a calcium sensor domain and a kinase domain combined in one protein. CPKs have a C-terminal calmodulin-like domain that contains EF-hand motifs, which can directly bind to calcium. At low calcium concentration, kinases are autoinhibited; however, calcium is elevated during the response to different stimuli and initiates an interaction with EF-hands and changes its conformation that relieves the kinase auto-inhibition [103]. CPKs' sensitivity to calcium varies greatly, with some CPKs such as CPK23 found to be insensitive to calcium [110,111]. CIB/CIPKs and CPKs share many targets for protein phosphorylation $[109,112,113]$ (Table 1).

ABA receptor families of pyrabactin resistance 1/pyrabactin resistance 1-like (PYR/PYL) or receptor component of $\mathrm{ABA}$ receptor (RCAR) intracellularly perceive $\mathrm{ABA}$ and subsequently interact with PP2Cs clade A family (protein phosphatases of group C), resulting in phosphatase inactivation. In the absence of ABA, PP2Cs phosphatases de- 
phosphorylate and inactivate SnRK2s, CIPK, and CPK families [24,111,114-116]. Under drought conditions, $\mathrm{ABA}$, accumulated in the guard cell, is perceived by $\mathrm{ABA}$ receptors PYR/PYL, leading to PP2C inactivation and setting the different kinases free, such as OST1 to phosphorylate downstream targets and translate ABA signals into the appropriate cellular responses [117-119]. As for phosphatases, PP2Cs are a common target for calciumdependent and calcium-independent kinases [120]. These kinase-phosphatase pairs play crucial roles in guard cell potassium channels and anion channel regulation (Table 1).

Table 1. Signaling elements involved in the regulation of guard cell stress response stomatal closure.

\begin{tabular}{|c|c|c|c|c|c|c|c|}
\hline $\begin{array}{c}\text { Kinases/ } \\
\text { Phosphatase/ } \\
\text { Ions }\end{array}$ & Protein Family & $\begin{array}{c}\text { Target } \\
\text { Channels }\end{array}$ & Localization & $\begin{array}{l}\text { Channel } \\
\text { Family }\end{array}$ & Ion Flux & $\begin{array}{l}\text { Effect on } \\
\text { Channel } \\
\text { Activity }\end{array}$ & Reference \\
\hline \multirow{3}{*}{ OST1 } & \multirow{3}{*}{ SnRK2 } & KAT1 & PM & Shaker & $\mathrm{K}^{+}$influx & Deactivation & {$[121,122]$} \\
\hline & & SLAC1 & PM & SLAC/SLAH & $\mathrm{Cl}^{-}$efflux & Activation & {$[117,123]$} \\
\hline & & AtALMT12 & PM & ALMT & Malate efflux & Activation & [124] \\
\hline CIPK5 & SnRK3 & GORK & PM & Shaker & $\mathrm{K}^{+}$efflux & Activation & [125] \\
\hline \multirow{2}{*}{ CIPK6 } & \multirow{2}{*}{ SnRK3 } & AKT1 & PM & Shaker & $\mathrm{K}^{+}$influx & Activation & {$[114,115]$} \\
\hline & & AKT2 & PM & Shaker & $\mathrm{K}^{+}$influx & Activation & [126] \\
\hline \multirow{5}{*}{ CIPK23 } & \multirow{5}{*}{ SnRK3 } & AKT1 & PM & Shaker & $\mathrm{K}^{+}$influx & Activation & {$[114,127,128]$} \\
\hline & & SLAC1 & PM & SLAC/SLAH & $\mathrm{Cl}^{-}$efflux & Activation & [74] \\
\hline & & SLAH3 & PM & SLAC/SLAH & $\mathrm{Cl}^{-}$efflux & Activation & [74] \\
\hline & & CHL1 & PM & NRT1 & $\mathrm{NO}_{3}$ influx & Deactivation & [129] \\
\hline & & AtCLCa & Tonoplast & CLC & $\mathrm{NO}_{3}$ influx & Activation & [130-132] \\
\hline CBL1 & CBL & AKT1 & PM & Shaker & $\mathrm{K}^{+}$influx & Activation & [133] \\
\hline CBL4 & CBL & AKT1 & $\mathrm{PM}$ & Shaker & $\mathrm{K}^{+}$influx & Activation & [133] \\
\hline CBL9 & CBL & AKT1 & $\mathrm{PM}$ & Shaker & $\mathrm{K}^{+}$influx & Activation & [133] \\
\hline \multirow{4}{*}{ CPK3 } & \multirow{4}{*}{ CPK/CDPK } & KAT1/KAT2 & PM & Shaker & $\mathrm{K}^{+}$influx & Activation & [134] \\
\hline & & SLAC1 & PM & SLAC/SLAH & $\mathrm{Cl}^{-}$efflux & Activation & [116] \\
\hline & & GORK & PM & Shaker & $\mathrm{K}^{+}$efflux & Activation & [134] \\
\hline & & TPK1 & Tonoplast & TPK & $\mathrm{K}^{+}$influx & Activation & [135] \\
\hline \multirow{2}{*}{ СРК6 } & \multirow{2}{*}{ CPK/CDPK } & GORK & PM & Shaker & $\mathrm{K}^{+}$efflux & Activation & [134] \\
\hline & & SLAC1 & PM & SLAC/SLAH & $\mathrm{Cl}^{-}$efflux & Activation & {$[111,136,137]$} \\
\hline \multirow{2}{*}{ CPK13 } & \multirow{2}{*}{ CPK/CDPK } & KAT1/KAT2 & PM & Shaker & $\mathrm{K}^{+}$influx & Activation & [138] \\
\hline & & GORK & PM & Shaker & $\mathrm{K}^{+}$efflux & Activation & [134] \\
\hline \multirow{3}{*}{ СРК21 } & \multirow{3}{*}{ CPK/CDPK } & GORK & PM & Shaker & $\mathrm{K}^{+}$efflux & Activation & [139] \\
\hline & & SLAC1 & PM & SLAC/SLAH & $\mathrm{Cl}^{-}$efflux & Activation & [111] \\
\hline & & SLAH3 & PM & SLAC/SLAH & $\mathrm{Cl}^{-}$efflux & Activation & [24] \\
\hline CPK33 & CPK/CDPK & GORK & PM & Shaker & $\mathrm{K}^{+}$efflux & Activation & [134] \\
\hline ABI1 & Clade A PP2C & SLAC1 & PM & SLAC/SLAH & $\mathrm{Cl}^{-}$efflux & Deactivation & [140] \\
\hline ABI2 & Clade APP2Cs & GORK & PM & Shaker & $\mathrm{K}^{+}$efflux & Deactivation & [141] \\
\hline \multirow{3}{*}{ AtPP2CA } & \multirow{3}{*}{ Clade APP2Cs } & AKT2 & PM & Shaker & $\mathrm{K}^{+}$influx & Deactivation & {$[142,143]$} \\
\hline & & GORK & PM & Shaker & $\mathrm{K}^{+}$efflux & Deactivation & [141] \\
\hline & & SLAC1 & PM & SLAC/SLAH & $\mathrm{Cl}^{-}$efflux & Deactivation & [117] \\
\hline AIP1 & Clade APP2Cs & AKT1 & PM & Shaker & $\mathrm{K}^{+}$influx & Deactivation & {$[114,115]$} \\
\hline \multirow{2}{*}{ Calcium } & & AtALMT4 & Tonoplast & ALMT & Malate fluxes & Activation & [91] \\
\hline & - & AtALMT6 & Tonoplast & ALMT & Malate fluxes & Activation & {$[86]$} \\
\hline $\begin{array}{l}\text { Cytosolic } \\
\text { malate }\end{array}$ & - & AtALMT9 & Tonoplast & ALMT & $\mathrm{Cl}^{-}$efflux & Activation & [87] \\
\hline
\end{tabular}

While ABA-mediated stomatal closure is considered to be the core abiotic stress signaling pathway, there is evidence that it is intertwined with multiple other signaling pathways, including the calcium pathway [120,144]. In the guard cell, cytosolic calcium acts as a second messenger to regulate ion channels, primarily by activating S-type anion channels and down-regulation of $\mathrm{K}^{+}$in channels, thus inhibiting stomatal opening and mediating stomatal closure $[145,146]$. In plants, stress signals that increase cytosolic ABA levels also elevate cytosolic calcium signals, and several protein targets that are regulated in response to abiotic stimuli are regulated by both $\mathrm{ABA}$ and calcium-mediated 
signaling $[22,120,147]$. The SLAC1 and KAT1 channels-coordinated activity are clear examples of how ABA-mediated and calcium-mediated signaling are interconnected in response to environmental stimuli.

\section{Signaling Mechanisms in Guard Cell during Stress-Induced Stomatal Closure}

During drought, the anion effluxes and the associated potassium release from the guard cells reduce the guard cell turgor pressure and lead to stomatal closure. The ABA hormone regulates such guard cell activities through the coordinated activation and inhibition of the PM anion and cation channels. ABA levels in guard cells rise due to de novo biosynthesis, recycling inactive conjugates (such as ABA glycose ester; ABA-GE) via $\beta$-glucosidases BG1 and BG2, and import, while they decline as a result of hydroxylation, conjugation, and export [148-150]. During plant water stress in Arabidopsis, nitrate transporter 1/peptide transporter family (NPF) member NPF4.6, and ABCG40 the ATP-binding cassette transporter are ABA importers, whereas DTX50 (from the multidrug and toxin efflux (MATE) transporter family) and AtABCG25 are ABA exporters [151-154] (for review, see References [155-158]). It has been suggested that rapid stomatal response under abiotic stress may depend mainly on ABA synthesized in the guard cell (autonomous synthesis in the guard cell), whereas in the long term soil water shortage, ABA synthesized in the vascular may play a significant role $[148,158]$. In the guard cell, increased cytosolic ABA hormone activates both S- and R-type anion channels [159,160]. The core of the ABA signaling cascade is the activation of the key OST1 kinase, which is achieved when cytosolic $A B A$ binds to ABA receptors (PYR/PYL/RCAR) and the protein phosphatase ABI1, subsequently resulting in ABI1 inactivation [100,118,161,162]. Activated OST1 phosphorylates the N-terminus of S-type anion channel SLAC1, which results in unlatching the phenyl ring that occludes the channel pore and thus activates the channel $[80,81,117,123,163]$. Ost1 mutants show low S-type anion channel activity and were unable to induce guard cell stomatal closure [123]. OST1 can also phosphorylate and inactivate KAT1 to reduce the potassium influx to the guard cell, which asserts its significance in stomatal closure [121,122]. In addition, ABA-activated OST1 can phosphorylate NADPH oxidase RbohF and RbohD, resulting in reactive oxygen species (ROS) being produced in the guard cell leading to the stomatal closure $[121,163,164]$. Two more kinases, mitogen-activated protein kinase 9 (MPK9) and MPK12, can induce ROS-mediated S-type anion channel activation in the guard cell during ABA signaling [165,166]. Upon ROS production, ABI2 not ABI1 was inhibited, suggesting its indirect role in enhancing the activity of GHR1 [167-169]. Furthermore, ROS generation in the guard cell stimulates nitrate reductase 1 (NR1) to produce more nitric oxide (NO), which can be used to regulate stomatal movement [170-174]. Receptor-like plasma membrane kinase guard cell hydrogen peroxide resistant 1 (GRH1), was also identified as an ABA-dependent regulator for SLAC1 activation. Unlike OST1, GHR1 interacts with ABI2 phosphatase rather than ABI1 and may work in tandem with OST1 to close stomata in response to ABA [168]. A recent study showed that SLAC1 activation by GHR requires the interaction of calcium dependent protein kinase CPK3 with GHR1 and that GHR1 has a scaffold function in stomatal closure [175]. In ABA-induced stomatal closure, brassinosteroid insensitive 1-associated receptor kinase 1 (BAK1) formed a complex with OST1 in response to ABA in planta that enhances stomatal closure. BAK1-OST1 complex formation is inhibited by ABI1 signifying the importance of ABI1 in OST1 regulation [176]. A recent study showed BAK1-flagellin sensing 2 (FLS2) complex, physically interacts with stress-induced factor 2 (SIF2) receptor like-kinase and phosphorylate and activates SLAC1 which induces stomatal closure upon bacterial invasion. In addition, the sif2-1 mutant was defective in response to ABA, signifying SIF2 importance in ABA-mediated stomatal closure (Figure 4) [177].

Recently, several members of the Raf/M3Ks (MAPKK-kinase family) that can regulate SnRK2 kinases in the ABA signaling pathway were identified [178-181]. These studies have revealed novel roles for the B2/B3 family of Raf/M3Ks in modulating the ABA signaling pathway via phosphorylation of SnRK2s from subclass III, and for the B4 family 
of Raf/M3Ks kinases in modulating the ABA-independent signaling pathway via phosphorylation of SnRK2s from subclass I under osmotic stress [178-182] (for review, see reference [183]). For instance, Takahashi et al., identified members of the M3Ks (MAPKKkinase family) that can activate SnRK2 kinases in response to ABA. The study showed M3Ks can phospho-activate SnRK2s and SLAC1 activation in planta in an ABA-dependent manner and the plants with triple M3K knockout have impaired ABA stress response [179]. On the contrary, Arabidopsis C family members of Raf/M3Ks (Raf36 and Raf22) negatively regulate ABA signaling and under abiotic stress, SnRK2 phosphorylate and promote Raf36 degradation [184].

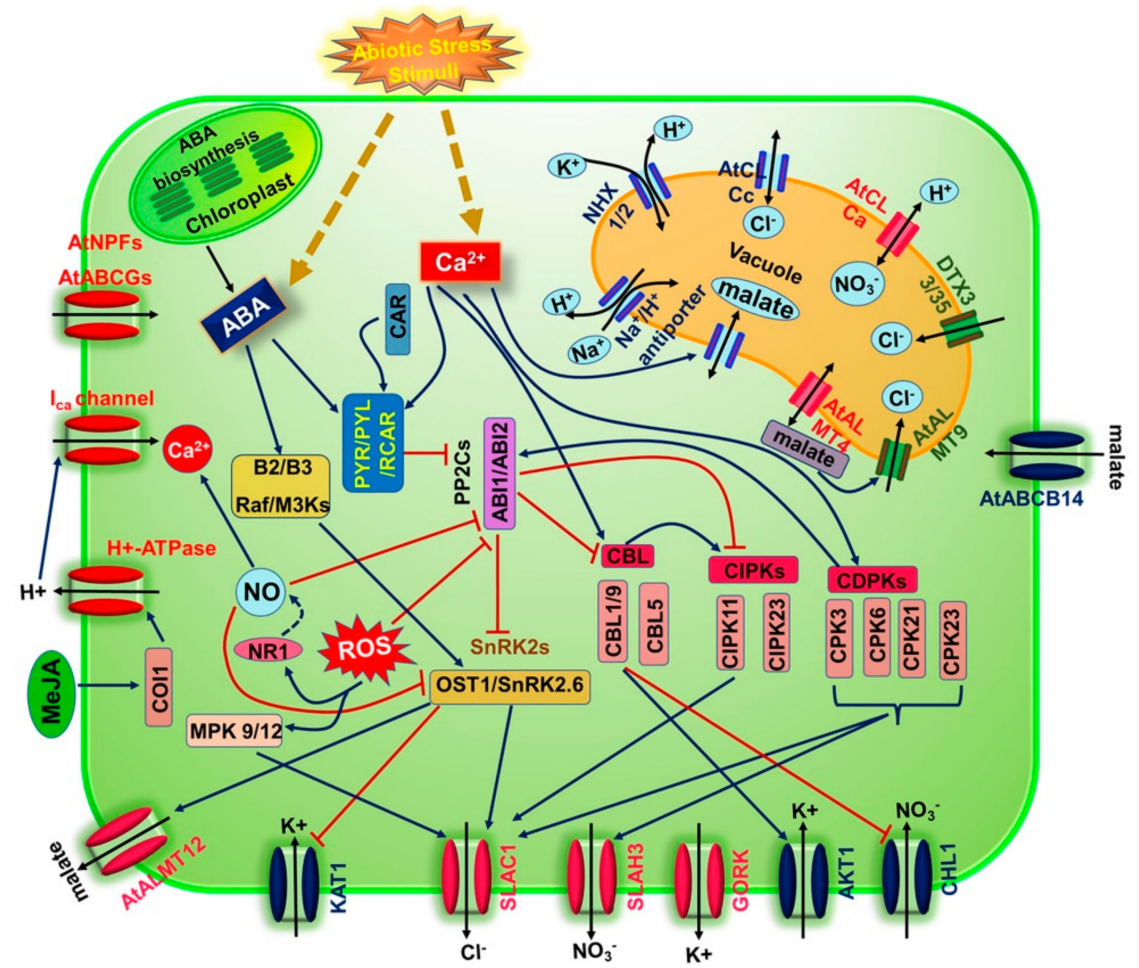

Figure 4. The schematic diagram represents the regulation of ion channels involved in the stomatal movement induced by stress in Arabidopsis thaliana. Channels that participate in stomatal closing or opening are colored in pink or blue, respectively. The arrows through the channels are ion effluxes/influx (black); straight arrows (blue), and broken arrows (red) are activation and inhibition respectively. Channels colored in green; the role they play during stomatal movement still needs further investigation.

On the other hand, ABA increases cytosolic calcium concentrations that can activate S-and R-type anion channels and inhibit proton pumps causing plasma membrane depolarization, which leads to $\mathrm{K}^{+}$in channels inhibition and $\mathrm{K}^{+}$out activation $[43,67-69,185,186]$. The increase in cytosolic calcium concentration is achieved by the calcium influx into the guard cell through calcium transporters and calcium release from its intracellular stores [21,68,187-191]. It is known that ABA induces the production of ROS that increases cytosolic calcium concentrations via the activation of calcium-permeable $\mathrm{I}_{\mathrm{Ca}}$ channels $[147,169,192,193]$. CBL1/CBL9 is activated when calcium levels rise, forming a complex with CIPK26 and phosphorylating RbohF, increasing ROS production via a positive feedback loop [194,195]. Similarly, calcium activates CPK4, 5, 6, and $11 \mathrm{ki}-$ nases that phosphorylate RbohD positively, hence regulating ROS production $[196,197]$. Additionally, the accumulated ROS promotes NO synthesis, which in turn releases calcium from intracellular calcium stores $[173,198,199]$. The increase in calcium concentration by these different mechanisms activates different CPKs in the guard cell, leading to phosphorylation and activation of the key SLAC1 anion channel. The kinases that activate SLAC1 are CIPK11/CBL5, CIPK23/CBL1or CBL9, and CPK3, 6, 21, 23 [74,111,116,140,200]. Although 
these kinases activate SLAC1 in Xenopus oocytes, they phosphorylate different residues from OST1 (for example, CPK phosphorylates S59 at the SLAC1 N-terminus) [74,140]. Several studies showed the presence of sophisticated cross-talk between SLAC1-regulating kinases, as both calcium-dependent protein kinases and OST1 activity are inhibited by ABI1and ABI2 $[74,111,113,140]$. CPK sensitivity for calcium activation varies between these family members. For instance, CPK21 is highly sensitive to calcium, whereas CPK23 is weakly sensitive to calcium [111]. However, SLAC1 activation in planta appears to be much more complex regarding both kinases' dependence. Arabidopsis plant lines with impaired function of triple mutants SnRK2S (snrk2.2/2.3/2.6) or CPK quadruple mutant plants (cpk5/6/11/23) show no SLAC1 activity and no stomatal closure in response to calcium or ABA [137]. According to Huang et al., most of the $\mathrm{Ca}^{2+}$ signals are elicited during the acceleration phase of stomatal closure, which is triggered by OST1 suggesting that these signals will boost stomatal closure via enhancing the S-anion channel activity [144]. These findings indicate that SLAC1 boosted activation required a joined function of CPKs and SnRK2s. Additionally, CBL5-CIPK11 and CBL1/9-CIPK23 showed SLAC1 activity in oocytes and CBL1/9 showed an impaired stomatal response (Figure 4) $[74,114,200]$.

ABA-induced S-type anion channel activity was disrupted when cpk3cpk6 or cpk5cpk6cpk11cpk23 mutations were introduced [136,137], while in planta, these mutants showed impaired stomatal closure upon ABA induction. There are some confusing results reported from calcium-dependent protein kinases activity experiments and that might be due to the functional overlap between these kinases. Even though CPK21 activation by 14-3-3 proteins activates the $\mathrm{K}^{+}$out channel, GORK, and coordinates with SLAC1 for stomatal closure, the cpk21 mutant showed greater tolerance to osmotic stress $[139,201,202]$. SLAH3 along with SLAC1 anion channel activities are required for stomatal closure $[203,204]$. Unlike SLAC1, SLAH3 cannot be activated by calcium-independent OST1 kinase [24]. However, the calcium-dependent protein kinases that activate SLAC1 can also activate SLAH3 such as CIPK23-CBL1/CBL9, CPK3, CPK6, CPK21, and CPK23 [24,74,75]. Interestingly, Zhang et al. reported that SLAC1 and SLAH3 can interact and inactivate KAT1 [72]. The nitrate transporter CHL1 is expressed in the guard cell and participates in nitrate build-up in the guard cell and contributes to stomatal opening. Similar to SLAH3, CHL1 is phosphorylated by CIPK23-CBL1/CBL9, reducing the nitrate intake (negatively regulated) and may have crosstalk between them [129,205-207].

In Arabidopsis, the ALMT12 channel is considered the main constituent of the R-type anion channels in the guard cell $[16,26,82]$. When OST1 and ALMT12 are co-expressed in Xenopus oocytes, there is a marked R-type anion channel activation indicating that OST1 plays a role in R-type anion channel activation [124]. In Arabidopsis, slac1, slah3, or almt12 single mutant retained some stomatal response to ABA, reduced air humidity, and elevated $\mathrm{CO}_{2}$, whereas slac1-almt12 double mutant has almost no response to these stimuli, signifying the importance of $S$ and R-type anion channels coordinated activation in stomatal closure [208]. The AtALMT12 C-terminus, located at the cytosol, acts as a sensor and the channel is inactivated when the membrane potential is hyperpolarized [83]. A Patch-clamp study showed that malate-dependent ALMT12 activity is dependent on cytosolic calcium and the channel current increased with the increasing cytosolic calcium concentration. The study further shows that the channel is co-regulated by calmodulin indicating a complex regulation mechanism for ALMT12 [209].

The GORK channel represents the major voltage-gated $\mathrm{K}^{+}$out channel in the guard cell and the absence of GORK activity impaired stomatal closure $[25,210]$. The PM depolarization activates GORK to induce potassium efflux; however, Ooi et al. reported that the direct interaction between ABA and GORK enhances the potassium efflux through the GORK channel and such a mechanism can represent a rapid stomatal response to environmental stimuli, rather than the conventional ABA signaling [211]. Nonetheless, Förster et al. showed that wound-triggered jasmonic acid (JA) hormone signaling can phospho-activate the GORK channel through the CBL1-CIPK5 kinase complex in coordination with the ABA signaling cascade [125]. Furthermore, the GORK channel may operate as ligand-gated 
channels as they possess binding domains that enable them to be modulated by different molecules such as G-proteins, inositol, protein phosphatases, ATP, cyclic nucleotides, and gamma-aminobutyric acid under environmental stresses (Figure 4) [212].

Although little is known about ions released from the vacuoles, potassium fluxes across the tonoplast play an essential role in controlling stomatal movement. The TPK1 vacuole potassium channel appears to be the main player in this process. Upon calcium elevation in the cytosol, TPK1 tonoplast channel activation by CPK3 plays a role in stomatal closure $[135,213]$. Furthermore, in response to ABA, Kinase 7 (KIN7), a receptor-like kinase, phosphorylates and activates the TPK1 channel, resulting in stomatal closure $[214,215]$. Taken together, the drought hormone ABA is perceived in the guard cell cytoplasm by ABA-receptors, which might act as a signal cascade that forks into calcium-independent and calcium-dependent branches [216,217]. Calcium-independent OST1 kinase activates the S-and R-type anion channels in the PM and mediates the release of anions from the guard cell. On the other hand, the elevated ABA causes an elevation in cytosolic calcium through calcium uptake as well as calcium release during a process regulated by ROS and nitric oxide $[167,173,218,219]$, which in turn leads to S-and R-type anion channel activation and PM depolarization [220]. The depolarized PM inactivates $\mathrm{K}^{+}$in channels and triggers the activation of the $\mathrm{K}^{+}$out channel to induce potassium efflux. The released ions drive water out of the guard cells lowering turgor pressure and causing stomatal closure $[25,210,221,222]$.

\section{Conclusions}

Understanding how the guard cell adapts to different environmental stimuli and deciphering the underlying signaling mechanisms and structural aspects will provide an insight into guard cell response modulated by different stimuli as well as offers knowledge of signal transduction in plants. Stomatal movement in response to abiotic stress such as drought is regulated via a complex signaling mechanism that involves different guard cell ion channels and their regulatory signaling components, such as hormones, calcium, protein kinases, NO, ROS, and receptors. In this mini-review, we described the recent advances in understanding how coordinated activities of the ion channels in the guard cell provide a defensive mechanism for plants to cope with different environmental stress conditions. Despite our tremendous knowledge of the guard cell signaling cascades, and their involvement in plant adaptation to abiotic stress, gaps in our knowledge remain and many questions remain unanswered, such as how SLAC1 structure conformation changes upon phosphorylation, the structural basis for the anion channels' anion selectivity, the guard cell calcium channel molecular aspects and their connection to calcium signaling pathways and the oligomerization of the guard cell channels and the role it plays in the regulation of plants' abiotic stress. Lately use of Cryogenic electron microscopy has been a revelation in identifying the structure of several plants' ion channels and can be a key to solving the molecular structures of many unidentified plant ion channels in the near future. Integrated studies of structural insights into these different ion channels at the molecular level, as well as studies of their physiological mechanisms, might broaden our understanding of signaling mechanisms and signal transduction during various abiotic stresses. Such comprehension and information will aid in engineering plants with improved responses to drought, higher $\mathrm{CO}_{2}$ levels, and other environmental stresses.

Author Contributions: Conceptualization, H.K.; Writing-original draft preparation, H.K.; Writingreview and editing, K.-H.B.; Funding acquisition, K.-H.B. All authors have read and agreed to the published version of the manuscript.

Funding: This research was supported by the Basic Science Research Program through the National Research Foundation of Korea (NRF) funded by the Ministry of Education (NRF-2021R1F1A1060297).

Institutional Review Board Statement: Not applicable.

Informed Consent Statement: Not applicable. 


\section{Data Availability Statement: Not applicable.}

Conflicts of Interest: The authors declare no conflict of interest.

\section{References}

1. Hetherington, A.; Woodward, F. The role of stomata in sensing and driving environmental change. Nature 2003, 424, 901-908. [CrossRef] [PubMed]

2. Sirichandra, C.; Wasilewska, A.; Vlad, F.; Valon, C.; Leung, J. The guard cell as a single-cell model towards understanding drought tolerance and abscisic acid action. J. Exp. Bot. 2009, 60, 1439-1463. [CrossRef] [PubMed]

3. De Boeck, H.J.; Dreesen, F.E.; Janssens, I.A.; Nijs, I. Whole-system responses of experimental plant communities to climate extremes imposed in different seasons. New Phytol. 2011, 189, 806-817. [CrossRef] [PubMed]

4. Fahad, S.; Bajwa, A.A.; Nazir, U.; Anjum, S.A.; Farooq, A.; Zohaib, A.; Sadia, S.; Nasim, W.; Adkins, S.; Saud, S.; et al. Crop Production under Drought and Heat Stress: Plant Responses and Management Options. Front. Plant Sci. 2017, 8, 1147. [CrossRef]

5. Lamaoui, M.; Jemo, M.; Datla, R.; Bekkaoui, F. Heat and Drought Stresses in Crops and Approaches for Their Mitigation. Front. Chem. 2018, 6, 26. [CrossRef]

6. Nakamura, R.L.; McKendree, W.L., Jr.; Hirsch, R.E.; Sedbrook, J.C.; Gaber, R.F.; Sussman, M.R. Expression of an Arabidopsis Potassium Channel Gene in Guard Cells. Plant Physiol. 1995, 109, 371-374. [CrossRef]

7. Kwak, J.M.; Murata, Y.; Baizabal-Aguirre, V.M.; Merrill, J.; Wang, M.; Kemper, A.; Hawke, S.D.; Tallman, G.; Schroeder, J.I. Dominant Negative Guard Cell $\mathrm{K}^{+}$Channel Mutants Reduce Inward-Rectifying $\mathrm{K}^{+}$Currents and Light-Induced Stomatal Opening in Arabidopsis. Plant Physiol. 2001, 127, 473-485. [CrossRef]

8. Pilot, G.; Lacombe, B.; Gaymard, F.; Chérel, I.; Boucherez, J.; Thibaud, J.-B.; Sentenac, H. Guard Cell Inward K+ Channel Activity in Arabidopsis Involves Expression of the Twin Channel Subunits KAT1 and KAT2. J. Biol. Chem. 2001, 276, 3215-3221. [CrossRef]

9. Szyroki, A.; Ivashikina, N.; Dietrich, P.; Roelfsema, M.R.G.; Ache, P.; Reintanz, B.; Deeken, R.; Godde, M.; Felle, H.; Steinmeyer, R.; et al. KAT1 is not essential for stomatal opening. Proc. Natl. Acad. Sci. USA 2001, 98, 2917-2921. [CrossRef]

10. Nieves-Cordones, M.; Caballero, F.; Martínez, V.; Rubio, F. Disruption of the arabidopsis thaliana inward-rectifier $\mathrm{K}^{+}$channel AKT1 improves plant responses to water stress. Plant Cell Physiol. 2012, 53, 423-432. [CrossRef]

11. Sharma, T.; Dreyer, I.; Riedelsberger, J. The role of $\mathrm{K}^{+}$channels in uptake and redistribution of potassium in the model plant Arabidopsis thaliana. Front. Plant Sci. 2013, 4, 224. [CrossRef]

12. Shimazaki, K.; Doi, M.; Assmann, S.M.; Kinoshita, T. Light Regulation of Stomatal Movement. Annu. Rev. Plant Biol. 2007, 58, 219-247. [CrossRef]

13. Lebaudy, A.; Vavasseur, A.; Hosy, E.; Dreyer, I.; Leonhardt, N.; Thibaud, J.-B.B.; Véry, A.-A.A.; Simonneau, T.; Sentenac, H. Plant adaptation to fluctuating environment and biomass production are strongly dependent on guard cell potassium channels. Proc. Natl. Acad. Sci. USA 2008, 105, 5271-5276. [CrossRef]

14. MacRobbie, E.A.C. ABA-induced ion efflux in stomatal guard cells: Multiple actions of ABA inside and outside the cell. Plant J. 1995, 7, 565-576. [CrossRef]

15. MacRobbie, E.A.C. Signal transduction and ion channels in guard cells. Philos. Trans. R. Soc. B Biol. Sci. 1998, 353, 1475-1488. [CrossRef]

16. Meyer, S.; Mumm, P.; Imes, D.; Endler, A.; Weder, B.; Al-Rasheid, K.A.S.; Geiger, D.; Marten, I.; Martinoia, E.; Hedrich, R.; et al. AtALMT12 represents an R-type anion channel required for stomatal movement in Arabidopsis guard cells. Plant J. 2010, 63, 1054-1062. [CrossRef]

17. Negi, J.; Matsuda, O.; Nagasawa, T.; Oba, Y.; Takahashi, H.; Kawai-Yamada, M.; Uchimiya, H.; Hashimoto, M.; Iba, K. CO 2 regulator SLAC1 and its homologues are essential for anion homeostasis in plant cells. Nature 2008, 452, 483-486. [CrossRef]

18. Vahisalu, T.; Kollist, H.; Wang, Y.-F.F.; Nishimura, N.; Chan, W.-Y.Y.; Valerio, G.; Lamminmäki, A.; Brosché, M.; Moldau, H.; Desikan, R.; et al. SLAC1 is required for plant guard cell S-type anion channel function in stomatal signalling. Nature 2008, 452, 487-491. [CrossRef]

19. Schroeder, J.I.; Allen, G.J.; Hugouvieux, V.; Kwak, J.M.; Waner, D. Guard cell signal transduction. Annu. Rev. Plant Physiol. Plant Mol. Biol. 2001, 52, 627-658. [CrossRef]

20. Hetherington, A.M. Guard cell signaling. Cell 2001, 107, 711-714. [CrossRef]

21. Hamilton, D.W.A.; Hills, A.; Kohler, B.; Blatt, M.R. Ca ${ }^{2+}$ channels at the plasma membrane of stomatal guard cells are activated by hyperpolarization and abscisic acid. Proc. Natl. Acad. Sci. USA 2000, 97, 4967-4972. [CrossRef]

22. Kwak, J.M.; Mäser, P.; Schroeder, J.I. The Clickable Guard Cell, Version II: Interactive Model of Guard Cell Signal Transduction Mechanisms and Pathways. In The Arabidopsis book; American Society of Plant Biologists: Rockville, MD, USA, 2008, Volume 6, p. e0114. [CrossRef]

23. Schroeder, J.I.; Raschke, K.; Neher, E. Voltage dependence of $\mathrm{K}^{+}$channels in guard-cell protoplasts. Proc. Natl. Acad. Sci. USA 1987, 84, 4108-4112. [CrossRef]

24. Geiger, D.; Maierhofer, T.; Al-Rasheid, K.A.S.S.; Scherzer, S.; Mumm, P.; Liese, A.; Ache, P.; Wellmann, C.; Marten, I.; Grill, E.; et al. Stomatal closure by fast abscisic acid signaling is mediated by the guard cell anion channel SLAH3 and the receptor RCAR1. Sci. Signal. 2011, 4, ra32. [CrossRef]

25. Hosy, E.; Vavasseur, A.; Mouline, K.; Dreyer, I.; Gaymard, F.; Poree, F.; Boucherez, J.; Lebaudy, A.; Bouchez, D.; Very, A.-A.; et al. The Arabidopsis outward $\mathrm{K}^{+}$channel GORK is involved in regulation of stomatal movements and plant transpiration. Proc. Natl. Acad. Sci. USA 2003, 100, 5549-5554. [CrossRef] 
26. Sasaki, T.; Mori, I.C.; Furuichi, T.; Munemasa, S.; Toyooka, K.; Matsuoka, K.; Murata, Y.; Yamamoto, Y. Closing plant stomata requires a homolog of an aluminum-activated malate transporter. Plant Cell Physiol. 2010, 51, 354-365. [CrossRef]

27. Huang, S.; Ding, M.; Roelfsema, M.R.G.; Dreyer, I.; Scherzer, S.; Al-Rasheid, K.A.S.; Gao, S.; Nagel, G.; Hedrich, R.; Konrad, K.R. Optogenetic control of the guard cell membrane potential and stomatal movement by the light-gated anion channel GtACR1. Sci. Adv. 2021, 7, eabg4619. [CrossRef]

28. Zhu, J.-K. Abiotic Stress Signaling and Responses in Plants. Cell 2016, 167, 313-324. [CrossRef]

29. Tuteja, N. Abscisic Acid and Abiotic Stress Signaling. Plant Signal. Behav. 2007, 2, 135-138. [CrossRef]

30. Hong, J.H.; Seah, S.W.; Xu, J. The root of ABA action in environmental stress response. Plant Cell Rep. 2013, 32, 971-983. [CrossRef]

31. Sah, S.K.; Reddy, K.R.; Li, J. Abscisic Acid and Abiotic Stress Tolerance in Crop Plants. Front. Plant Sci. 2016, 7, 571. [CrossRef] [PubMed]

32. Demidchik, V. ROS-Activated Ion Channels in Plants: Biophysical Characteristics, Physiological Functions and Molecular Nature. Int. J. Mol. Sci. 2018, 19, 1263. [CrossRef] [PubMed]

33. Postiglione, A.E.; Muday, G.K. The Role of ROS Homeostasis in ABA-Induced Guard Cell Signaling. Front. Plant Sci. 2020, 11, 968. [CrossRef] [PubMed]

34. Demidchik, V. Mechanisms of oxidative stress in plants: From classical chemistry to cell biology. Environ. Exp. Bot. 2015, 109, 212-228. [CrossRef]

35. Nolan, T.; Chen, J.; Yin, Y. Cross-talk of Brassinosteroid signaling in controlling growth and stress responses. Biochem. J. 2017, 474, 2641-2661. [CrossRef]

36. Planas-Riverola, A.; Gupta, A.; Betegón-Putze, I.; Bosch, N.; Ibañes, M.; Caño-Delgado, A.I. Brassinosteroid signaling in plant development and adaptation to stress. Development 2019, 146, dev151894. [CrossRef]

37. Hafeez, M.B.; Zahra, N.; Zahra, K.; Raza, A.; Khan, A.; Shaukat, K.; Khan, S. Brassinosteroids: Molecular and physiological responses in plant growth and abiotic stresses. Plant Stress 2021, 2, 100029. [CrossRef]

38. Ward, J.M.; Mäser, P.; Schroeder, J.I. Plant Ion Channels: Gene Families, Physiology, and Functional Genomics Analyses. Annu. Rev. Physiol. 2009, 71, 59-82. [CrossRef]

39. Hedrich, R. Ion channels in plants. Physiol. Rev. 2012, 92, 1777-1811. [CrossRef]

40. Lebaudy, A.; Hosy, E.; Simonneau, T.; Sentenac, H.; Thibaud, J.; Dreyer, I. Heteromeric $\mathrm{K}^{+}$channels in plants. Plant J. 2008, 54, 1076-1082. [CrossRef]

41. Dreyer, I.; Blatt, M.R. What makes a gate? The ins and outs of Kv-like $\mathrm{K}^{+}$channels in plants. Trends Plant Sci. 2009, 14, 383-390. [CrossRef]

42. Ivashikina, N.; Deeken, R.; Fischer, S.; Ache, P.; Hedrich, R. AKT2/3 Subunits Render Guard Cell $\mathrm{K}^{+} \mathrm{Channels} \mathrm{Ca}^{2+}$ Sensitive. J. Gen. Physiol. 2005, 125, 483-492. [CrossRef]

43. Kinoshita, T.; Nishimura, M.; Shimazaki, K. Cytosolic Concentration of $\mathrm{Ca}^{2+}$ Regulates the Plasma Membrane $\mathrm{H}^{+}-\mathrm{ATPase}$ in Guard Cells of Fava Bean. Plant Cell 1995, 7, 1333-1342. [CrossRef]

44. Kinoshita, T. Blue light activates the plasma membrane $\mathrm{H}^{+}$-ATPase by phosphorylation of the C-terminus in stomatal guard cells. EMBO J. 1999, 18, 5548-5558. [CrossRef]

45. Zhang, X.; Wang, H.; Takemiya, A.; Song, C.; Kinoshita, T.; Shimazaki, K. Inhibition of Blue Light-Dependent $\mathrm{H}^{+}$Pumping by Abscisic Acid through Hydrogen Peroxide-Induced Dephosphorylation of the Plasma Membrane $\mathrm{H}^{+}$-ATPase in Guard Cell Protoplasts. Plant Physiol. 2004, 136, 4150-4158. [CrossRef]

46. Roelfsema, M.R.G.; Steinmeyer, R.; Staal, M.; Hedrich, R. Single guard cell recordings in intact plants: Light-induced hyperpolarization of the plasma membrane. Plant J. 2001, 26, 1-13. [CrossRef]

47. Kinoshita, T.; Emi, T.; Tominaga, M.; Sakamoto, K.; Shigenaga, A.; Doi, M.; Shimazaki, K. Blue-Light- and PhosphorylationDependent Binding of a 14-3-3 Protein to Phototropins in Stomatal Guard Cells of Broad Bean. Plant Physiol. 2003, 133, 1453-1463. [CrossRef]

48. Schroeder, J.I.; Kwak, J.M.; Allen, G.J. Guard cell abscisic acid signalling and engineering drought hardiness in plants. Nature 2001, 410, 327-330. [CrossRef]

49. Schroeder, J.I.; Hedrich, R.; Fernandez, J.M. Potassium-selective single channels in guard cell protoplasts of Vicia faba. Nature 1984, 312, 361-362. [CrossRef]

50. Pantoja, O. Recent Advances in the Physiology of Ion Channels in Plants. Annu. Rev. Plant Biol. 2021, 72, 463-495. [CrossRef]

51. Falhof, J.; Pedersen, J.T.; Fuglsang, A.T.; Palmgren, M. Plasma Membrane $\mathrm{H}^{+}$-ATPase Regulation in the Center of Plant Physiology. Mol. Plant 2016, 9, 323-337. [CrossRef]

52. Kim, T.H.; Böhmer, M.; Hu, H.; Nishimura, N.; Schroeder, J.I. Guard cell signal transduction network: Advances in understanding abscisic acid, $\mathrm{CO}_{2}$, and $\mathrm{Ca}^{2+}$ signaling. Annu. Rev. Plant Biol. 2010, 61, 561-591. [CrossRef]

53. Pandey, S.; Zhang, W.; Assmann, S.M. Roles of ion channels and transporters in guard cell signal transduction. FEBS Lett. 2007, 581, 2325-2336. [CrossRef] [PubMed]

54. Dreyer, I.; Antunes, S.; Hoshi, T.; Müller-Röber, B.; Palme, K.; Pongs, O.; Reintanz, B.; Hedrich, R. Plant K ${ }^{+}$channel alpha-subunits assemble indiscriminately. Biophys. J. 1997, 72, 2143-2150. [CrossRef]

55. Xicluna, J.; Lacombe, B.; Dreyer, I.; Alcon, C.; Jeanguenin, L.; Sentenac, H.; Thibaud, J.-B.; Chérel, I. Increased Functional Diversity of Plant $\mathrm{K}^{+}$Channels by Preferential Heteromerization of the Shaker-like Subunits AKT2 and KAT2. J. Biol. Chem. 2007, 282, 486-494. [CrossRef] [PubMed] 
56. Lebaudy, A.; Pascaud, F.; Véry, A.-A.; Alcon, C.; Dreyer, I.; Thibaud, J.-B.; Lacombe, B. Preferential KAT1-KAT2 Heteromerization Determines Inward $\mathrm{K}^{+}$Current Properties in Arabidopsis Guard Cells. J. Biol. Chem. 2010, 285, 6265-6274. [CrossRef] [PubMed]

57. Benito, B.; Haro, R.; Amtmann, A.; Cuin, T.A.; Dreyer, I. The twins $\mathrm{K}^{+}$and $\mathrm{Na}^{+}$in plants. J. Plant Physiol. 2014, 171, 723-731. [CrossRef] [PubMed]

58. Jiang, Y.; Lee, A.; Chen, J.; Ruta, V.; Cadene, M.; Chait, B.T.; MacKinnon, R. X-ray structure of a voltage-dependent $\mathrm{K}^{+}$channel. Nature 2003, 423, 33-41. [CrossRef] [PubMed]

59. Long, S.B.; Campbell, E.B.; MacKinnon, R. Crystal Structure of a Mammalian Voltage-Dependent Shaker Family K ${ }^{+}$Channel. Science 2005, 309, 897-903. [CrossRef]

60. Véry, A.-A.A.; Nieves-Cordones, M.; Daly, M.; Khan, I.; Fizames, C.; Sentenac, H. Molecular biology of K ${ }^{+}$transport across the plant cell membrane: What do we learn from comparison between plant species? J. Plant Physiol. 2014, 171, 748-769. [CrossRef]

61. Lefoulon, C. The bare necessities of plant $\mathrm{K}^{+}$channel regulation. Plant Physiol. 2021, 187, 2092-2109. [CrossRef]

62. Ichida, A.M.; Pei, Z.M.; Baizabal-Aguirre, V.M.; Turner, K.J.; Schroeder, J.I. Expression of a Cs(+)-resistant guard cell K ${ }^{+}$channel confers Cs(+)-resistant, light-induced stomatal opening in transgenic arabidopsis. Plant Cell 1997, 9, 1843-1857. [CrossRef]

63. Iosip, A.L.; Böhm, J.; Scherzer, S.; Al-Rasheid, K.A.S.; Dreyer, I.; Schultz, J.; Becker, D.; Kreuzer, I.; Hedrich, R. The Venus flytrap trigger hair-specific potassium channel KDM1 can reestablish the $\mathrm{K}^{+}$gradient required for hapto-electric signaling. PLoS Biol. 2020, 18, e3000964. [CrossRef]

64. Clark, M.D.; Contreras, G.F.; Shen, R.; Perozo, E. Electromechanical coupling in the hyperpolarization-activated K ${ }^{+}$channel KAT1. Nature 2020, 583, 145-149. [CrossRef]

65. Li, S.; Yang, F.; Sun, D.; Zhang, Y.; Zhang, M.; Liu, S.; Zhou, P.; Shi, C.; Zhang, L.; Tian, C. Cryo-EM structure of the hyperpolarization-activated inwardly rectifying potassium channel KAT1 from Arabidopsis. Cell Res. 2020, 30, 1049-1052. [CrossRef]

66. DeLano, W. Pymol; The PyMOL Molecular Graphics System, Version 2; Schrödinger Inc.: New York, NY, USA, 2020.

67. Schroeder, J.I.; Keller, B.U. Two types of anion channel currents in guard cells with distinct voltage regulation. Proc. Natl. Acad. Sci. USA 1992, 89, 5025-5029. [CrossRef]

68. Schroeder, J.I.; Hagiwara, S. Cytosolic calcium regulates ion channels in the plasma membrane of Vicia faba guard cells. Nature 1989, 338, 427-430. [CrossRef]

69. Hedrich, R.; Busch, H.; Raschke, K. $\mathrm{Ca}^{2+}$ and nucleotide dependent regulation of voltage dependent anion channels in the plasma membrane of guard cells. EMBO J. 1990, 9, 3889-3892. [CrossRef]

70. Linder, B.; Raschke, K. A slow anion channel in guard cells, activating at large hyperpolarization, may be principal for stomatal closing. FEBS Lett. 1992, 313, 27-30. [CrossRef]

71. Dreyer, I.; Gomez-Porras, J.L.; Riaño-Pachón, D.M.; Hedrich, R.; Geiger, D. Molecular evolution of slow and quick anion channels (SLACs and QUACs/ALMTs). Front. Plant Sci. 2012, 3, 263. [CrossRef]

72. Zhang, A.; Ren, H.M.; Tan, Y.Q.; Qi, G.N.; Yao, F.Y.; Wu, G.L.; Yang, L.W.; Hussain, J.; Sun, S.J.; Wanga, Y.F. S-type anion channels SLAC1 and SLAH3 function as essential negative regulators of inward $\mathrm{K}^{+}$channels and stomatal opening in arabidopsis. Plant Cell 2016, 28, 949-965. [CrossRef]

73. Cubero-Font, P.; Maierhofer, T.; Jaslan, J.; Rosales, M.A.; Espartero, J.; Díaz-Rueda, P.; Müller, H.M.; Hürter, A.L.; AL-Rasheid, K.A.S.S.; Marten, I.; et al. Silent S-Type Anion Channel Subunit SLAH1 Gates SLAH3 Open for Chloride Root-to-Shoot Translocation. Curr. Biol. 2016, 26, 2213-2220. [CrossRef]

74. Maierhofer, T.; Diekmann, M.; Offenborn, J.N.; Lind, C.; Bauer, H.; Hashimoto, K.; Al-Rasheid, K.A.S.S.; Luan, S.; Kudla, J.; Geiger, D.; et al. Site-and kinase-specific phosphorylation-mediated activation of SLAC1, a guard cell anion channel stimulated by abscisic acid. Sci. Signal. 2014, 7, ra86. [CrossRef]

75. Demir, F.; Horntrich, C.; Blachutzik, J.O.; Scherzer, S.; Reinders, Y.; Kierszniowska, S.; Schulze, W.X.; Harms, G.S.; Hedrich, R.; Geiger, D.; et al. Arabidopsis nanodomain-delimited ABA signaling pathway regulates the anion channel SLAH3. Proc. Natl. Acad. Sci. USA 2013, 110, 8296-8301. [CrossRef]

76. Liu, Y.; Maierhofer, T.; Rybak, K.; Sklenar, J.; Breakspear, A.; Johnston, M.G.; Fliegmann, J.; Huang, S.; Roelfsema, M.R.G.; Felix, G.; et al. Anion channel SLAH3 is a regulatory target of chitin receptor-associated kinase PBL27 in microbial stomatal closure. eLife 2019, 8, e44474. [CrossRef]

77. Lehmann, J.; Jørgensen, M.E.; Fratz, S.; Müller, H.M.; Kusch, J.; Scherzer, S.; Navarro-Retamal, C.; Mayer, D.; Böhm, J.; Konrad, K.R.; et al. Acidosis-induced activation of anion channel SLAH3 in the flooding-related stress response of Arabidopsis. Curr. Biol. 2021, 31, 3575-3585.e9. [CrossRef]

78. Qiu, J.; Henderson, S.W.; Tester, M.; Roy, S.J.; Gilliham, M. SLAH1, a homologue of the slow type anion channel SLAC1, modulates shoot $\mathrm{Cl}^{-}$accumulation and salt tolerance in Arabidopsis thaliana. J. Exp. Bot. 2017, 68, 4495-4505. [CrossRef]

79. Maierhofer, T.; Lind, C.; Hüttl, S.; Scherzer, S.; Papenfuß, M.; Simon, J.; Al-Rasheid, K.A.S.S.; Ache, P.; Rennenberg, H.; Hedrich, R.; et al. A single-pore residue renders the Arabidopsis root anion channel SLAH2 highly nitrate selective. Plant Cell 2014, 26, 2554-2567. [CrossRef] [PubMed]

80. Deng, Y.; Kashtoh, H.; Wang, Q.; Zhen, G.; Li, Q.; Tang, L.; Gao, H.; Zhang, C.; Qin, L.; Su, M.; et al. Structure and activity of SLAC1 channels for stomatal signaling in leaves. Proc. Natl. Acad. Sci. USA 2021, 118, e2015151118. [CrossRef] [PubMed]

81. Chen, Y.H.; Hu, L.; Punta, M.; Bruni, R.; Hillerich, B.; Kloss, B.; Rost, B.; Love, J.; Siegelbaum, S.A.; Hendrickson, W.A. Homologue structure of the SLAC1 anion channel for closing stomata in leaves. Nature 2010, 467, 1074-1080. [CrossRef] 
82. Barbier-Brygoo, H.; De Angeli, A.; Filleur, S.; Frachisse, J.-M.; Gambale, F.; Thomine, S.; Wege, S. Anion Channels/Transporters in Plants: From Molecular Bases to Regulatory Networks. Annu. Rev. Plant Biol. 2011, 62, 25-51. [CrossRef]

83. Mumm, P.; Imes, D.; Martinoia, E.; Al-Rasheid, K.A.S.; Geiger, D.; Marten, I.; Hedrich, R. C-Terminus-Mediated Voltage Gating of Arabidopsis Guard Cell Anion Channel QUAC1. Mol. Plant 2013, 6, 1550-1563. [CrossRef]

84. Hoekenga, O.A.; Maron, L.G.; Pineros, M.A.; Cancado, G.M.A.; Shaff, J.; Kobayashi, Y.; Ryan, P.R.; Dong, B.; Delhaize, E.; Sasaki, T.; et al. AtALMT1, which encodes a malate transporter, is identified as one of several genes critical for aluminum tolerance in Arabidopsis. Proc. Natl. Acad. Sci. USA 2006, 103, 9738-9743. [CrossRef]

85. Qin, L.; Tang, L.; Xu, J.; Zhang, X.; Zhu, Y.; Zhang, C.; Liu, X.; Wang, M.; Li, F.; Sun, F. Molecular basis for the R-type anion channel QUAC1 activity in guard cells. bioRxiv 2021. [CrossRef]

86. Meyer, S.; Scholz-Starke, J.; De Angeli, A.; Kovermann, P.; Burla, B.; Gambale, F.; Martinoia, E. Malate transport by the vacuolar AtALMT6 channel in guard cells is subject to multiple regulation. Plant J. 2011, 67, 247-257. [CrossRef]

87. De Angeli, A.; Zhang, J.; Meyer, S.; Martinoia, E. AtALMT9 is a malate-activated vacuolar chloride channel required for stomatal opening in Arabidopsis. Nat. Commun. 2013, 4, 1804. [CrossRef]

88. Kovermann, P.; Meyer, S.; Hörtensteiner, S.; Picco, C.; Scholz-Starke, J.; Ravera, S.; Lee, Y.; Martinoia, E. The Arabidopsis vacuolar malate channel is a member of the ALMT family. Plant J. 2007, 52, 1169-1180. [CrossRef]

89. Eisenach, C.; De Angeli, A. Ion Transport at the Vacuole during Stomatal Movements. Plant Physiol. 2017, 174, 520-530. [CrossRef]

90. Ye, W.; Koya, S.; Hayashi, Y.; Jiang, H.; Oishi, T.; Kato, K.; Fukatsu, K.; Kinoshita, T. Identification of Genes Preferentially Expressed in Stomatal Guard Cells of Arabidopsis thaliana and Involvement of the Aluminum-Activated Malate Transporter 6 Vacuolar Malate Channel in Stomatal Opening. Front. Plant Sci. 2021, 12, 2203. [CrossRef]

91. Eisenach, C.; Baetz, U.; Huck, N.V.; Zhang, J.; De Angeli, A.; Beckers, G.J.M.M.; Martinoia, E. ABA-induced stomatal closure involves ALMT4, a phosphorylation-dependent vacuolar anion channel of Arabidopsis. Plant Cell 2017, 29, 2552-2569. [CrossRef]

92. Lee, M.; Choi, Y.; Burla, B.; Kim, Y.-Y.; Jeon, B.; Maeshima, M.; Yoo, J.-Y.; Martinoia, E.; Lee, Y. The ABC transporter AtABCB14 is a malate importer and modulates stomatal response to CO2. Nat. Cell Biol. 2008, 10, 1217-1223. [CrossRef]

93. Wang, C.; Zhang, J.; Wu, J.; Brodsky, D.E.; Schroeder, J.I. Cytosolic malate and oxaloacetate activate S-type anion channels in Arabidopsis guard cells. New Phytol. 2018, 220, 178-186. [CrossRef]

94. Chater, C.; Peng, K.; Movahedi, M.; Dunn, J.A.; Walker, H.J.; Liang, Y.K.; McLachlan, D.H.; Casson, S.; Isner, J.C.; Wilson, I.; et al. Elevated $\mathrm{CO}_{2}$-Induced Responses in Stomata Require ABA and ABA Signaling. Curr. Biol. 2015, 25, 2709-2716. [CrossRef]

95. Cutler, S.R.; Rodriguez, P.L.; Finkelstein, R.R.; Abrams, S.R. Abscisic Acid: Emergence of a Core Signaling Network. Annu. Rev. Plant Biol. 2010, 61, 651-679. [CrossRef]

96. Munemasa, S.; Hauser, F.; Park, J.; Waadt, R.; Brandt, B.; Schroeder, J.I. Mechanisms of abscisic acid-mediated control of stomatal aperture. Curr. Opin. Plant Biol. 2015, 28, 154-162. [CrossRef]

97. Zhang, Y.; Lv, Y.; Jahan, N.; Chen, G.; Ren, D.; Guo, L. Sensing of Abiotic Stress and Ionic Stress Responses in Plants. Int. J. Mol. Sci. 2018, 19, 3298. [CrossRef]

98. Coello, P.; Hey, S.J.; Halford, N.G. The sucrose non-fermenting-1-related (SnRK) family of protein kinases: Potential for manipulation to improve stress tolerance and increase yield. J. Exp. Bot. 2011, 62, 883-893. [CrossRef]

99. Halford, N.G.; Hey, S.J. Snf1-related protein kinases (SnRKs) act within an intricate network that links metabolic and stress signalling in plants. Biochem. J. 2009, 419, 247-259. [CrossRef] [PubMed]

100. Mustilli, A.-C.; Merlot, S.; Vavasseur, A.; Fenzi, F.; Giraudat, J. Arabidopsis OST1 Protein Kinase Mediates the Regulation of Stomatal Aperture by Abscisic Acid and Acts Upstream of Reactive Oxygen Species Production. Plant Cell 2002, 14, 3089-3099. [CrossRef] [PubMed]

101. Kleist, T.J.; Luan, S. Constant change: Dynamic regulation of membrane transport by calcium signalling networks keeps plants in tune with their environment. Plant. Cell Environ. 2016, 39, 467-481. [CrossRef] [PubMed]

102. Kudla, J.; Becker, D.; Grill, E.; Hedrich, R.; Hippler, M.; Kummer, U.; Parniske, M.; Romeis, T.; Schumacher, K. Advances and current challenges in calcium signaling. New Phytol. 2018, 218, 414-431. [CrossRef]

103. Boudsocq, M.; Sheen, J. CDPKs in immune and stress signaling. Trends Plant Sci. 2013, 18, 30-40. [CrossRef]

104. Steinhorst, L.; Kudla, J. Signaling in cells and organisms-Calcium holds the line. Curr. Opin. Plant Biol. 2014, 22, 14-21. [CrossRef]

105. Hashimoto, K.; Kudla, J. Calcium decoding mechanisms in plants. Biochimie 2011, 93, 2054-2059. [CrossRef]

106. Batistič, O.; Kudla, J. Analysis of calcium signaling pathways in plants. Biochim. Biophys. Acta Gen. Subj. 2012, 1820, 1283-1293. [CrossRef]

107. Kudla, J.; Xu, Q.; Harter, K.; Gruissem, W.; Luan, S. Genes for calcineurin B-like proteins in Arabidopsis are differentially regulated by stress signals. Proc. Natl. Acad. Sci. USA 1999, 96, 4718-4723. [CrossRef]

108. Shi, J.; Kim, K.-N.; Ritz, O.; Albrecht, V.; Gupta, R.; Harter, K.; Luan, S.; Kudla, J. Novel Protein Kinases Associated with Calcineurin B-like Calcium Sensors in Arabidopsis. Plant Cell 1999, 11, 2393-2405. [CrossRef]

109. Chaves-Sanjuan, A.; Sanchez-Barrena, M.J.; Gonzalez-Rubio, J.M.; Moreno, M.; Ragel, P.; Jimenez, M.; Pardo, J.M.; Martinez-Ripoll, M.; Quintero, F.J.; Albert, A. Structural basis of the regulatory mechanism of the plant CIPK family of protein kinases controlling ion homeostasis and abiotic stress. Proc. Natl. Acad. Sci. USA 2014, 111, E4532-E4541. [CrossRef]

110. Boudsocq, M.; Droillard, M.-J.; Regad, L.; Laurière, C. Characterization of Arabidopsis calcium-dependent protein kinases: Activated or not by calcium? Biochem. J. 2012, 447, 291-299. [CrossRef] 
111. Geiger, D.; Scherzer, S.; Mumm, P.; Marten, I.; Ache, P.; Matschi, S.; Liese, A.; Wellmann, C.; Al-Rasheid, K.A.S.S.; Grill, E.; et al. Guard cell anion channel SLAC1 is regulated by CDPK protein kinases with distinct $\mathrm{Ca}^{2+}$ affinities. Proc. Natl. Acad. Sci. USA 2010, 107, 8023-8028. [CrossRef]

112. Hashimoto, K.; Eckert, C.; Anschütz, U.; Scholz, M.; Held, K.; Waadt, R.; Reyer, A.; Hippler, M.; Becker, D.; Kudla, J. Phosphorylation of Calcineurin B-like (CBL) Calcium Sensor Proteins by Their CBL-interacting Protein Kinases (CIPKs) Is Required for Full Activity of CBL-CIPK Complexes toward Their Target Proteins. J. Biol. Chem. 2012, 287, 7956-7968. [CrossRef]

113. Mao, J.; Manik, S.; Shi, S.; Chao, J.; Jin, Y.; Wang, Q.; Liu, H. Mechanisms and Physiological Roles of the CBL-CIPK Networking System in Arabidopsis thaliana. Genes 2016, 7, 62. [CrossRef]

114. Lee, S.C.; Lan, W.-Z.; Kim, B.-G.; Li, L.; Cheong, Y.H.; Pandey, G.K.; Lu, G.; Buchanan, B.B.; Luan, S. A protein phosphorylation/dephosphorylation network regulates a plant potassium channel. Proc. Natl. Acad. Sci. USA 2007, 104, 15959-15964. [CrossRef]

115. Lan, W.-Z.; Lee, S.-C.; Che, Y.-F.; Jiang, Y.-Q.; Luan, S. Mechanistic Analysis of AKT1 Regulation by the CBL-CIPK-PP2CA Interactions. Mol. Plant 2011, 4, 527-536. [CrossRef]

116. Scherzer, S.; Maierhofer, T.; Al-Rasheid, K.A.S.S.; Geiger, D.; Hedrich, R. Multiple calcium-dependent kinases modulate ABAactivated guard cell anion channels. Mol. Plant 2012, 5, 1409-1412. [CrossRef]

117. Lee, S.C.; Lan, W.; Buchanan, B.B.; Luan, S. A protein kinase-phosphatase pair interacts with an ion channel to regulate ABA signaling in plant guard cells. Proc. Natl. Acad. Sci. USA 2009, 106, 21419-21424. [CrossRef]

118. Ma, Y.; Szostkiewicz, I.; Korte, A.; Moes, D.; Yang, Y.; Christmann, A.; Grill, E. Regulators of PP2C Phosphatase Activity Function as Abscisic Acid Sensors. Science 2009, 324, 1064-1068. [CrossRef]

119. Soon, F.F.; Ng, L.M.; Zhou, X.E.; West, G.M.; Kovach, A.; Tan, M.H.E.; Suino-Powell, K.M.; He, Y.; Xu, Y.; Chalmers, M.J.; et al. Molecular mimicry regulates ABA signaling by SnRK2 kinases and PP2C phosphatases. Science 2012, 335, 85-88. [CrossRef] [PubMed]

120. Edel, K.H.; Kudla, J. Integration of calcium and ABA signaling. Curr. Opin. Plant Biol. 2016, 33, 83-91. [CrossRef] [PubMed]

121. Acharya, B.R.; Jeon, B.W.; Zhang, W.; Assmann, S.M. Open Stomata 1 (OST1) is limiting in abscisic acid responses of Arabidopsis guard cells. New Phytol. 2013, 200, 1049-1063. [CrossRef] [PubMed]

122. Sato, A.; Sato, Y.; Fukao, Y.; Fujiwara, M.; Umezawa, T.; Shinozaki, K.; Hibi, T.; Taniguchi, M.; Miyake, H.; Goto, D.B.; et al. Threonine at position 306 of the KAT1 potassium channel is essential for channel activity and is a target site for ABA-activated SnRK2/OST1/SnRK2.6 protein kinase. Biochem. J. 2009, 424, 439-448. [CrossRef]

123. Geiger, D.; Scherzer, S.; Mumm, P.; Stange, A.; Marten, I.; Bauer, H.; Ache, P.; Matschi, S.; Liese, A.; Al-Rasheid, K.A.S.S.; et al Activity of guard cell anion channel SLAC1 is controlled by drought-stress signaling kinase-phosphatase pair. Proc. Natl. Acad. Sci. USA 2009, 106, 21425-21430. [CrossRef]

124. Imes, D.; Mumm, P.; Böhm, J.; Al-Rasheid, K.A.S.S.; Marten, I.; Geiger, D.; Hedrich, R. Open stomata 1 (OST1) kinase controls R-type anion channel QUAC1 in Arabidopsis guard cells. Plant J. 2013, 74, 372-382. [CrossRef]

125. Förster, S.; Schmidt, L.K.; Kopic, E.; Anschütz, U.; Huang, S.; Schlücking, K.; Köster, P.; Waadt, R.; Larrieu, A.; Batistič, O.; et al. Wounding-Induced Stomatal Closure Requires Jasmonate-Mediated Activation of GORK K ${ }^{+} \mathrm{Channels}_{\text {by a Ca }}{ }^{2+}$ Sensor-Kinase CBL1-CIPK5 Complex. Dev. Cell 2019, 48, 87-99.e6. [CrossRef]

126. Held, K.; Pascaud, F.; Eckert, C.; Gajdanowicz, P.; Hashimoto, K.; Corratgé-Faillie, C.; Offenborn, J.N.; Lacombe, B.; Dreyer, I.; Thibaud, J.-B.; et al. Calcium-dependent modulation and plasma membrane targeting of the AKT2 potassium channel by the CBL4/CIPK6 calcium sensor/protein kinase complex. Cell Res. 2011, 21, 1116-1130. [CrossRef]

127. Xu, J.; Li, H.-D.; Chen, L.-Q.; Wang, Y.; Liu, L.-L.; He, L.; Wu, W.-H. A Protein Kinase, Interacting with Two Calcineurin B-like Proteins, Regulates $\mathrm{K}^{+}$Transporter AKT1 in Arabidopsis. Cell 2006, 125, 1347-1360. [CrossRef]

128. Li, L.; Kim, B.-G.; Cheong, Y.H.; Pandey, G.K.; Luan, S. A Ca ${ }^{2+}$ signaling pathway regulates a $\mathrm{K}^{+}$channel for low-K response in Arabidopsis. Proc. Natl. Acad. Sci. USA 2006, 103, 12625-12630. [CrossRef]

129. Ho, C.-H.; Lin, S.-H.; Hu, H.-C.; Tsay, Y.-F. CHL1 Functions as a Nitrate Sensor in Plants. Cell 2009, 138, 1184-1194. [CrossRef]

130. De Angeli, A.; Monachello, D.; Ephritikhine, G.; Frachisse, J.M.; Thomine, S.; Gambale, F.; Barbier-Brygoo, H. The nitrate/proton antiporter AtCLCa mediates nitrate accumulation in plant vacuoles. Nature 2006, 442, 939-942. [CrossRef]

131. Wege, S.; De Angeli, A.; Droillard, M.-J.J.; Kroniewicz, L.; Merlot, S.; Cornu, D.; Gambale, F.; Martinoia, E.; Barbier-Brygoo, H.H.; Thomine, S.S.; et al. Phosphorylation of the vacuolar anion exchanger AtCLCa is required for the stomatal response to abscisic acid. Sci. Signal. 2014, 7, ra65. [CrossRef]

132. De Angeli, A.; Moran, O.; Wege, S.; Filleur, S.; Ephritikhine, G.; Thomine, S.; Barbier-Brygoo, H.; Gambale, F. ATP Binding to the C Terminus of the Arabidopsis thaliana Nitrate/Proton Antiporter, AtCLCa, Regulates Nitrate Transport into Plant Vacuoles. J. Biol. Chem. 2009, 284, 26526-26532. [CrossRef]

133. Grefen, C.; Karnik, R.; Larson, E.; Lefoulon, C.; Wang, Y.; Waghmare, S.; Zhang, B.; Hills, A.; Blatt, M.R. A vesicle-trafficking protein commandeers $\mathrm{Kv}$ channel voltage sensors for voltage-dependent secretion. Nat. Plants 2015, 1, 15108. [CrossRef]

134. Corratgé-Faillie, C.; Ronzier, E.; Sanchez, F.; Prado, K.; Kim, J.; Lanciano, S.; Leonhardt, N.; Lacombe, B.; Xiong, T.C. The Arabidopsis guard cell outward potassium channel GORK is regulated by CPK33. FEBS Lett. 2017, 591, 1982-1992. [CrossRef]

135. Latz, A.; Mehlmer, N.; Zapf, S.; Mueller, T.D.; Wurzinger, B.; Pfister, B.; Csaszar, E.; Hedrich, R.; Teige, M.; Becker, D. Salt Stress Triggers Phosphorylation of the Arabidopsis Vacuolar K+ Channel TPK1 by Calcium-Dependent Protein Kinases (CDPKs). Mol. Plant 2013, 6, 1274-1289. [CrossRef] 
136. Mori, I.C.; Murata, Y.; Yang, Y.; Munemasa, S.; Wang, Y.-F.F.; Andreoli, S.; Tiriac, H.; Alonso, J.M.; Harper, J.F.; Ecker, J.R.; et al. CDPKs CPK6 and CPK3 function in ABA regulation of guard cell S-type anion- and $\mathrm{Ca}^{2+}$-Permeable channels and stomatal closure. PLoS Biol. 2006, 4, 1749-1762. [CrossRef]

137. Brandt, B.; Munemasa, S.; Wang, C.; Nguyen, D.; Yong, T.; Yang, P.G.; Poretsky, E.; Belknap, T.F.; Waadt, R.; Alemán, F.; et al. Calcium specificity signaling mechanisms in abscisic acid signal transduction in arabidopsis guard cells. eLife 2015, 4, e03599. [CrossRef]

138. Ronzier, E.; Corratgé-Faillie, C.; Sanchez, F.; Prado, K.; Brière, C.; Leonhardt, N.; Thibaud, J.-B.; Xiong, T.C. CPK13, a Noncanonical $\mathrm{Ca}^{2+}$-Dependent Protein Kinase, Specifically Inhibits KAT2 and KAT1 Shaker $\mathrm{K}^{+}$Channels and Reduces Stomatal Opening. Plant Physiol. 2014, 166, 314-326. [CrossRef]

139. Van Kleeff, P.J.M.; Gao, J.; Mol, S.; Zwart, N.; Zhang, H.; Li, K.W.; de Boer, A.H. The Arabidopsis GORK $\mathrm{K}^{+}$-channel is phosphorylated by calcium-dependent protein kinase 21 (CPK21), which in turn is activated by 14-3-3 proteins. Plant Physiol. Biochem. 2018, 125, 219-231. [CrossRef]

140. Brandt, B.; Brodsky, D.E.; Xue, S.; Negi, J.; Iba, K.; Kangasjärvi, J.; Ghassemian, M.; Stephan, A.B.; Hu, H.; Schroeder, J.I. Reconstitution of abscisic acid activation of SLAC1 anion channel by CPK6 and OST1 kinases and branched ABI1 PP2C phosphatase action. Proc. Natl. Acad. Sci. USA 2012, 109, 10593-10598. [CrossRef]

141. Lefoulon, C.; Boeglin, M.; Moreau, B.; Véry, A.-A.; Szponarski, W.; Dauzat, M.; Michard, E.; Gaillard, I.; Chérel, I. The Arabidopsis AtPP2CA Protein Phosphatase Inhibits the GORK K ${ }^{+}$Efflux Channel and Exerts a Dominant Suppressive Effect on Phosphomimetic-activating Mutations. J. Biol. Chem. 2016, 291, 6521-6533. [CrossRef]

142. Vranová, E.; Tähtiharju, S.; Sriprang, R.; Willekens, H.; Heino, P.; Tapio Palva, E.; Inzé, D.; Van Camp, W. The AKT3 potassium channel protein interacts with the AtPP2CA protein phosphatase 2C. J. Exp. Bot. 2001, 52, 181-182. [CrossRef] [PubMed]

143. Chérel, I.; Michard, E.; Platet, N.; Mouline, K.; Alcon, C.; Sentenac, H.; Thibaud, J.-B. Physical and Functional Interaction of the Arabidopsis $\mathrm{K}^{+}$Channel AKT2 and Phosphatase AtPP2CA. Plant Cell 2002, 14, 1133-1146. [CrossRef]

144. Huang, S.; Waadt, R.; Nuhkat, M.; Kollist, H.; Hedrich, R.; Roelfsema, M.R.G. Calcium signals in guard cells enhance the efficiency by which abscisic acid triggers stomatal closure. New Phytol. 2019, 224, 177-187. [CrossRef]

145. Laanemets, K.; Brandt, B.; Li, J.; Merilo, E.; Wang, Y.F.; Keshwani, M.M.; Taylor, S.S.; Kollist, H.; Schroeder, J.I. Calcium-dependent and independent stomatal signaling network and compensatory feedback control of stomatal opening via $\mathrm{Ca}^{2+}$ sensitivity priming. Plant Physiol. 2013, 163, 504-513. [CrossRef] [PubMed]

146. Saito, S.; Uozumi, N. Calcium-Regulated Phosphorylation Systems Controlling Uptake and Balance of Plant Nutrients. Front. Plant Sci. 2020, 11, 44. [CrossRef] [PubMed]

147. Munemasa, S.; Muroyama, D.; Nagahashi, H.; Nakamura, Y.; Mori, I.C.; Murata, Y. Regulation of reactive oxygen species-mediated abscisic acid signaling in guard cells and drought tolerance by glutathione. Front. Plant Sci. 2013, 4, 472. [CrossRef] [PubMed]

148. Bauer, H.; Ache, P.; Lautner, S.; Fromm, J.; Hartung, W.; Al-Rasheid, K.A.S.; Sonnewald, S.; Sonnewald, U.; Kneitz, S.; Lachmann, N.; et al. The Stomatal Response to Reduced Relative Humidity Requires Guard Cell-Autonomous ABA Synthesis. Curr. Biol. 2013, 23, 53-57. [CrossRef] [PubMed]

149. Lee, K.H.; Piao, H.L.; Kim, H.-Y.; Choi, S.M.; Jiang, F.; Hartung, W.; Hwang, I.; Kwak, J.M.; Lee, I.-J.; Hwang, I. Activation of Glucosidase via Stress-Induced Polymerization Rapidly Increases Active Pools of Abscisic Acid. Cell 2006, 126, 1109-1120. [CrossRef]

150. Okamoto, M.; Tanaka, Y.; Abrams, S.R.; Kamiya, Y.; Seki, M.; Nambara, E. High Humidity Induces Abscisic Acid 8'-Hydroxylase in Stomata and Vasculature to Regulate Local and Systemic Abscisic Acid Responses in Arabidopsis. Plant Physiol. 2009, 149, 825-834. [CrossRef]

151. Kang, J.; Hwang, J.-U.; Lee, M.; Kim, Y.-Y.; Assmann, S.M.; Martinoia, E.; Lee, Y. PDR-type ABC transporter mediates cellular uptake of the phytohormone abscisic acid. Proc. Natl. Acad. Sci. USA 2010, 107, 2355-2360. [CrossRef]

152. Kuromori, T.; Miyaji, T.; Yabuuchi, H.; Shimizu, H.; Sugimoto, E.; Kamiya, A.; Moriyama, Y.; Shinozaki, K. ABC transporter AtABCG25 is involved in abscisic acid transport and responses. Proc. Natl. Acad. Sci. USA 2010, 107, 2361-2366. [CrossRef]

153. Kanno, Y.; Hanada, A.; Chiba, Y.; Ichikawa, T.; Nakazawa, M.; Matsui, M.; Koshiba, T.; Kamiya, Y.; Seo, M. Identification of an abscisic acid transporter by functional screening using the receptor complex as a sensor. Proc. Natl. Acad. Sci. USA 2012, 109, 9653-9658. [CrossRef]

154. Zhang, H.; Zhu, H.; Pan, Y.; Yu, Y.; Luan, S.; Li, L. A DTX/MATE-Type Transporter Facilitates Abscisic Acid Efflux and Modulates ABA Sensitivity and Drought Tolerance in Arabidopsis. Mol. Plant 2014, 7, 1522-1532. [CrossRef]

155. Chen, K.; Li, G.; Bressan, R.A.; Song, C.; Zhu, J.; Zhao, Y. Abscisic acid dynamics, signaling, and functions in plants. J. Integr. Plant Biol. 2020, 62, 25-54. [CrossRef]

156. Kuromori, T.; Seo, M.; Shinozaki, K. ABA Transport and Plant Water Stress Responses. Trends Plant Sci. 2018, 23, 513-522. [CrossRef]

157. Takahashi, F.; Kuromori, T.; Urano, K.; Yamaguchi-Shinozaki, K.; Shinozaki, K. Drought Stress Responses and Resistance in Plants: From Cellular Responses to Long-Distance Intercellular Communication. Front. Plant Sci. 2020, 11, 1407. [CrossRef]

158. Merilo, E.; Jalakas, P.; Laanemets, K.; Mohammadi, O.; Hõrak, H.; Kollist, H.; Brosché, M. Abscisic acid transport and homeostasis in the context of stomatal regulation. Mol. Plant 2015, 8, 1321-1333. [CrossRef]

159. Pei, Z.M.; Kuchitsu, K.; Ward, J.M.; Schwarz, M.; Schroeder, J.I. Differential abscisic acid regulation of guard cell slow anion channels in Arabidopsis wild-type and abi1 and abi2 mutants. Plant Cell 1997, 9, 409-423. [CrossRef]

160. Roelfsema, M.R.G.; Levchenko, V.; Hedrich, R. ABA depolarizes guard cells in intact plants, through a transient activation of Rand S-type anion channels. Plant J. 2004, 37, 578-588. [CrossRef] 
161. Yoshida, R.; Hobo, T.; Ichimura, K.; Mizoguchi, T.; Takahashi, F.; Aronso, J.; Ecker, J.R.; Shinozaki, K. ABA-Activated SnRK2 Protein Kinase is Required for Dehydration Stress Signaling in Arabidopsis. Plant Cell Physiol. 2002, 43, 1473-1483. [CrossRef]

162. Park, S.-Y.; Fung, P.; Nishimura, N.; Jensen, D.R.; Fujii, H.; Zhao, Y.; Lumba, S.; Santiago, J.; Rodrigues, A.; Chow, T.F.; et al. Abscisic Acid Inhibits Type 2C Protein Phosphatases via the PYR/PYL Family of START Proteins. Science 2009, 324, 1068-1071. [CrossRef] [PubMed]

163. Vahisalu, T.; Puzõrjova, I.; Brosché, M.; Valk, E.; Lepiku, M.; Moldau, H.; Pechter, P.; Wang, Y.S.; Lindgren, O.; Salojärvi, J.; et al. Ozone-triggered rapid stomatal response involves the production of reactive oxygen species, and is controlled by SLAC1 and OST1. Plant J. 2010, 62, 442-453. [CrossRef] [PubMed]

164. Sirichandra, C.; Gu, D.; Hu, H.-C.; Davanture, M.; Lee, S.; Djaoui, M.; Valot, B.; Zivy, M.; Leung, J.; Merlot, S.; et al. Phosphorylation of the Arabidopsis AtrbohF NADPH oxidase by OST1 protein kinase. FEBS Lett. 2009, 583, 2982-2986. [CrossRef] [PubMed]

165. Prodhan, M.Y.; Munemasa, S.; Nahar, M.N.E.N.; Nakamura, Y.; Murata, Y. Guard cell salicylic acid signaling is integrated into abscisic acid signaling via the $\mathrm{Ca}^{2+} / \mathrm{CPK}$-dependent pathway. Plant Physiol. 2018, 178, 441-450. [CrossRef]

166. Jammes, F.; Song, C.; Shin, D.; Munemasa, S.; Takeda, K.; Gu, D.; Cho, D.; Lee, S.; Giordo, R.; Sritubtim, S.; et al. MAP kinases MPK9 and MPK12 are preferentially expressed in guard cells and positively regulate ROS-mediated ABA signaling. Proc. Natl. Acad. Sci. USA 2009, 106, 20520-20525. [CrossRef]

167. Sierla, M.; Waszczak, C.; Vahisalu, T.; Kangasjärvi, J. Reactive Oxygen Species in the Regulation of Stomatal Movements. Plant Physiol. 2016, 171, 1569-1580. [CrossRef]

168. Hua, D.; Wang, C.; He, J.; Liao, H.; Duan, Y.; Zhu, Z.; Guo, Y.; Chen, Z.; Gong, Z. A Plasma Membrane Receptor Kinase, GHR1, Mediates Abscisic Acid- and Hydrogen Peroxide-Regulated Stomatal Movement in Arabidopsis. Plant Cell 2012, 24, 2546-2561. [CrossRef]

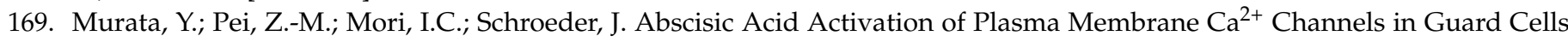
Requires Cytosolic NAD(P)H and Is Differentially Disrupted Upstream and Downstream of Reactive Oxygen Species Production in abi1-1 and abi2-1 Protein Phosphatase 2C Mutants. Plant Cell 2001, 13, 2513-2523. [CrossRef]

170. Bright, J.; Desikan, R.; Hancock, J.T.; Weir, I.S.; Neill, S.J. ABA-induced NO generation and stomatal closure in Arabidopsis are dependent on $\mathrm{H}_{2} \mathrm{O}_{2}$ synthesis. Plant J. 2006, 45, 113-122. [CrossRef]

171. Wilson, I.D.; Ribeiro, D.M.; Bright, J.; Confraria, A.; Harrison, J.; Barros, R.S.; Desikan, R.; Neill, S.J.; Hancock, J.T. Role of nitric oxide in regulating stomatal apertures. Plant Signal. Behav. 2009, 4, 467-469. [CrossRef]

172. Neill, S.; Barros, R.; Bright, J.; Desikan, R.; Hancock, J.; Harrison, J.; Morris, P.; Ribeiro, D.; Wilson, I. Nitric oxide, stomatal closure, and abiotic stress. J. Exp. Bot. 2008, 59, 165-176. [CrossRef]

173. Gayatri, G.; Agurla, S.; Raghavendra, A.S. Nitric oxide in guard cells as an important secondary messenger during stomatal closure. Front. Plant Sci. 2013, 4, 425. [CrossRef]

174. Laxalt, A.M.; García-Mata, C.; Lamattina, L. The Dual Role of Nitric Oxide in Guard Cells: Promoting and Attenuating the ABA and Phospholipid-Derived Signals Leading to the Stomatal Closure. Front. Plant Sci. 2016, 7, 476. [CrossRef]

175. Sierla, M.; Hõrak, H.; Overmyer, K.; Waszczak, C.; Yarmolinsky, D.; Maierhofer, T.; Vainonen, J.P.; Salojärvi, J.; Denessiouk, K.; Laanemets, K.; et al. The Receptor-like Pseudokinase GHR1 Is Required for Stomatal Closure. Plant Cell 2018, 30, 2813-2837. [CrossRef]

176. Shang, Y.; Dai, C.; Lee, M.M.; Kwak, J.M.; Nam, K.H. BRI1-Associated Receptor Kinase 1 Regulates Guard Cell ABA Signaling Mediated by Open Stomata 1 in Arabidopsis. Mol. Plant 2016, 9, 447-460. [CrossRef]

177. Chan, C.; Panzeri, D.; Okuma, E.; Tõldsepp, K.; Wang, Y.-Y.; Louh, G.-Y.; Chin, T.-C.; Yeh, Y.-H.; Yeh, H.-L.; Yekondi, S.; et al. STRESS INDUCED FACTOR 2 Regulates Arabidopsis Stomatal Immunity through Phosphorylation of the Anion Channel SLAC1. Plant Cell 2020, 32, 2216-2236. [CrossRef]

178. Saruhashi, M.; Ghosh, T.K.; Arai, K.; Ishizaki, Y.; Hagiwara, K.; Komatsu, K.; Shiwa, Y.; Izumikawa, K.; Yoshikawa, H.; Umezawa, T.; et al. Plant Raf-like kinase integrates abscisic acid and hyperosmotic stress signaling upstream of SNF1-related protein kinase2. Proc. Natl. Acad. Sci. USA 2015, 112, E6388-E6396. [CrossRef]

179. Takahashi, Y.; Zhang, J.; Hsu, P.-K.K.; Ceciliato, P.H.O.O.; Zhang, L.; Dubeaux, G.; Munemasa, S.; Ge, C.; Zhao, Y.; Hauser, F.; et al. MAP3Kinase-dependent SnRK2-kinase activation is required for abscisic acid signal transduction and rapid osmotic stress response. Nat. Commun. 2020, 11, 12. [CrossRef]

180. Lin, Z.; Li, Y.; Zhang, Z.; Liu, X.; Hsu, C.-C.; Du, Y.; Sang, T.; Zhu, C.; Wang, Y.; Satheesh, V.; et al. A RAF-SnRK2 kinase cascade mediates early osmotic stress signaling in higher plants. Nat. Commun. 2020, 11, 613. [CrossRef]

181. Katsuta, S.; Masuda, G.; Bak, H.; Shinozawa, A.; Kamiyama, Y.; Umezawa, T.; Takezawa, D.; Yotsui, I.; Taji, T.; Sakata, Y. Arabidopsis Raf-like kinases act as positive regulators of subclass III SnRK2 in osmostress signaling. Plant J. 2020, 103, 634-644. [CrossRef]

182. Soma, F.; Takahashi, F.; Suzuki, T.; Shinozaki, K.; Yamaguchi-Shinozaki, K. Plant Raf-like kinases regulate the mRNA population upstream of ABA-unresponsive SnRK2 kinases under drought stress. Nat. Commun. 2020, 11, 1373. [CrossRef]

183. Fàbregas, N.; Yoshida, T.; Fernie, A.R. Role of Raf-like kinases in SnRK2 activation and osmotic stress response in plants. Nat. Commun. 2020, 11, 6184. [CrossRef]

184. Kamiyama, Y.; Hirotani, M.; Ishikawa, S.; Minegishi, F.; Katagiri, S.; Rogan, C.J.; Takahashi, F.; Nomoto, M.; Ishikawa, K.; Kodama, Y.; et al. Arabidopsis group C Raf-like protein kinases negatively regulate abscisic acid signaling and are direct substrates of SnRK2. Proc. Natl. Acad. Sci. USA 2021, 118, e2100073118. [CrossRef] 
185. McAinsh, M.R.; Brownlee, C.; Hetherington, A.M. Abscisic acid-induced elevation of guard cell cytosolic Ca ${ }^{2+}$ precedes stomatal closure. Nature 1990, 343, 186-188. [CrossRef]

186. Brault, M.; Amiar, Z.; Pennarun, A.-M.; Monestiez, M.; Zhang, Z.; Cornel, D.; Dellis, O.; Knight, H.; Bouteau, F.; Rona, J.-P. Plasma Membrane Depolarization Induced by Abscisic Acid in Arabidopsis Suspension Cells Involves Reduction of Proton Pumping in Addition to Anion Channel Activation, Which Are Both $\mathrm{Ca}^{2+}$ Dependent. Plant Physiol. 2004, 135, 231-243. [CrossRef]

187. Schroeder, J.I.; Hagiwara, S. Repetitive increases in cytosolic $\mathrm{Ca}^{2+}$ of guard cells by abscisic acid activation of nonselective Ca ${ }^{2+}$ permeable channels. Proc. Natl. Acad. Sci. USA 1990, 87, 9305-9309. [CrossRef]

188. Grabov, A.; Blatt, M.R. Membrane voltage initiates $\mathrm{Ca}^{2+}$ waves and potentiates $\mathrm{Ca}^{2+}$ increases with abscisic acid in stomatal guard cells. Proc. Natl. Acad. Sci. USA 1998, 95, 4778-4783. [CrossRef]

189. Leckie, C.P.; McAinsh, M.R.; Allen, G.J.; Sanders, D.; Hetherington, A.M. Abscisic acid-induced stomatal closure mediated by cyclic ADP-ribose. Proc. Natl. Acad. Sci. USA 1998, 95, 15837-15842. [CrossRef]

190. Staxen, I.; Pical, C.; Montgomery, L.T.; Gray, J.E.; Hetherington, A.M.; McAinsh, M.R. Abscisic acid induces oscillations in guard-cell cytosolic free calcium that involve phosphoinositide-specific phospholipase C. Proc. Natl. Acad. Sci. USA 1999, 96, 1779-1784. [CrossRef]

191. MacRobbie, E.A.C. ABA activates multiple $\mathrm{Ca}^{2+}$ fluxes in stomatal guard cells, triggering vacuolar $\mathrm{K}^{+}(\mathrm{Rb}+)$ release. Proc. Natl. Acad. Sci. USA 2000, 97, 12361-12368. [CrossRef]

192. Pei, Z.-M.; Murata, Y.; Benning, G.; Thomine, S.; Klüsener, B.; Allen, G.J.; Grill, E.; Schroeder, J.I. Calcium channels activated by hydrogen peroxide mediate abscisic acidsignalling in guard cells. Nature 2000, 406, 731-734. [CrossRef]

193. Kwak, J.M. NADPH oxidase AtrbohD and AtrbohF genes function in ROS-dependent ABA signaling in Arabidopsis. EMBO J. 2003, 22, 2623-2633. [CrossRef]

194. Mittler, R.; Blumwald, E. The Roles of ROS and ABA in Systemic Acquired Acclimation. Plant Cell 2015, 27, 64-70. [CrossRef]

195. Drerup, M.M.; Schlücking, K.; Hashimoto, K.; Manishankar, P.; Steinhorst, L.; Kuchitsu, K.; Kudla, J. The Calcineurin B-Like Calcium Sensors CBL1 and CBL9 Together with Their Interacting Protein Kinase CIPK26 Regulate the Arabidopsis NADPH Oxidase RBOHF. Mol. Plant 2013, 6, 559-569. [CrossRef]

196. Boudsocq, M.; Willmann, M.R.; McCormack, M.; Lee, H.; Shan, L.; He, P.; Bush, J.; Cheng, S.-H.; Sheen, J. Differential innate immune signalling via $\mathrm{Ca}^{2+}$ sensor protein kinases. Nature 2010, 464, 418-422. [CrossRef]

197. Kadota, Y.; Shirasu, K.; Zipfel, C. Regulation of the NADPH Oxidase RBOHD During Plant Immunity. Plant Cell Physiol. 2015, 56, 1472-1480. [CrossRef]

198. Lamotte, O.; Courtois, C.; Dobrowolska, G.; Besson, A.; Pugin, A.; Wendehenne, D. Mechanisms of nitric-oxide-induced increase of free cytosolic $\mathrm{Ca}^{2+}$ concentration in Nicotiana plumbaginifolia cells. Free Radic. Biol. Med. 2006, 40, 1369-1376. [CrossRef]

199. Jeandroz, S.; Lamotte, O.; Astier, J.; Rasul, S.; Trapet, P.; Besson-Bard, A.; Bourque, S.; Nicolas-Francès, V.; Ma, W.; Berkowitz, G.A.; et al. There's More to the Picture Than Meets the Eye: Nitric Oxide Cross Talk with Ca2+ Signaling. Plant Physiol. 2013, 163, 459-470. [CrossRef]

200. Saito, S.; Hamamoto, S.; Moriya, K.; Matsuura, A.; Sato, Y.; Muto, J.; Noguchi, H.; Yamauchi, S.; Tozawa, Y.; Ueda, M.; et al. Nmyristoylation and S-acylation are common modifications of $\mathrm{Ca}^{2+}$-regulated Arabidopsis kinases and are required for activation of the SLAC1 anion channel. New Phytol. 2018, 218, 1504-1521. [CrossRef]

201. Franz, S.; Ehlert, B.; Liese, A.; Kurth, J.; Cazalé, A.-C.; Romeis, T. Calcium-dependent protein kinase CPK21 functions in abiotic stress response in Arabidopsis thaliana. Mol. Plant 2011, 4, 83-96. [CrossRef]

202. Martín, M.L.; Busconi, L. Membrane localization of a rice calcium-dependent protein kinase (CDPK) is mediated by myristoylation and palmitoylation. Plant J. 2008, 24, 429-435. [CrossRef]

203. Guzel Deger, A.; Scherzer, S.; Nuhkat, M.; Kedzierska, J.; Kollist, H.; Brosché, M.; Unyayar, S.; Boudsocq, M.; Hedrich, R.; Roelfsema, M.R.G. Guard cell SLAC1-type anion channels mediate flagellin-induced stomatal closure. New Phytol. 2015, 208, 162-173. [CrossRef]

204. Zheng, X.; Kang, S.; Jing, Y.; Ren, Z.; Li, L.; Zhou, J.M.; Berkowitz, G.; Shi, J.; Fu, A.; Lan, W.; et al. Danger-associated peptides close stomata by OST1-independent activation of anion channels in guard cells. Plant Cell 2018, 30, 1132-1146. [CrossRef]

205. Liu, K.; Tsay, Y. Switching between the two action modes of the dual-affinity nitrate transporter CHL1 by phosphorylation. EMBO J. 2003, 22, 1005-1013. [CrossRef]

206. Parker, J.L.; Newstead, S. Molecular basis of nitrate uptake by the plant nitrate transporter NRT1.1. Nature 2014, 507, 68-72. [CrossRef]

207. Léran, S.; Muños, S.; Brachet, C.; Tillard, P.; Gojon, A.; Lacombe, B. Arabidopsis NRT1.1 Is a Bidirectional Transporter Involved in Root-to-Shoot Nitrate Translocation. Mol. Plant 2013, 6, 1984-1987. [CrossRef]

208. Jalakas, P.; Nuhkat, M.; Vahisalu, T.; Merilo, E.; Brosché, M.; Kollist, H. Combined action of guard cell plasma membrane rapidand slow-type anionchannels in stomatal regulation. Plant Physiol. 2021, 187, 2126-2133. [CrossRef]

209. Luu, K.; Rajagopalan, N.; Ching, J.C.H.; Loewen, M.C.; Loewen, M.E. The malate-activated ALMT12 anion channel in the grass Brachypodium distachyon is co-activated by $\mathrm{Ca}^{2+} /$ calmodulin. J. Biol. Chem. 2019, 294, 6142-6156. [CrossRef]

210. Ache, P.; Becker, D.; Ivashikina, N.; Dietrich, P.; Roelfsema, M.R.G.; Hedrich, R. GORK, a delayed outward rectifier expressed in guard cells of Arabidopsis thaliana, is a $\mathrm{K}^{+}$-selective, $\mathrm{K}^{+}$-sensing ion channel. FEBS Lett. 2000, 486, 93-98. [CrossRef]

211. Ooi, A.; Lemtiri-Chlieh, F.; Wong, A.; Gehring, C. Direct Modulation of the Guard Cell Outward-Rectifying Potassium Channel (GORK) by Abscisic Acid. Mol. Plant 2017, 10, 1469-1472. [CrossRef] 
212. Adem, G.D.; Chen, G.; Shabala, L.; Chen, Z.-H.; Shabala, S. GORK Channel: A Master Switch of Plant Metabolism? Trends Plant Sci. 2020, 25, 434-445. [CrossRef]

213. Yang, Y.; Costa, A.; Leonhardt, N.; Siegel, R.S.; Schroeder, J.I. Isolation of a strong Arabidopsis guard cell promoter and its potential as a research tool. Plant Methods 2008, 4, 6. [CrossRef]

214. Gobert, A.; Isayenkov, S.; Voelker, C.; Czempinski, K.; Maathuis, F.J.M. The two-pore channel TPK1 gene encodes the vacuolar K ${ }^{+}$ conductance and plays a role in K+ homeostasis. Proc. Natl. Acad. Sci. USA 2007, 104, 10726-10731. [CrossRef]

215. Isner, J.C.; Begum, A.; Nuehse, T.; Hetherington, A.M.; Maathuis, F.J.M. KIN7 Kinase Regulates the Vacuolar TPK1 K+ Channel during Stomatal Closure. Curr. Biol. 2018, 28, 466-472.e4. [CrossRef]

216. Marten, H.; Konrad, K.R.; Dietrich, P.; Roelfsema, M.R.G.; Hedrich, R. Ca ${ }^{2+}$-dependent and -independent abscisic acid activation of plasma membrane anion channels in guard cells of Nicotiana tabacum. Plant Physiol. 2007, 143, 28-37. [CrossRef]

217. Siegel, R.S.; Xue, S.; Murata, Y.; Yang, Y.; Nishimura, N.; Wang, A.; Schroeder, J.I. Calcium elevation-dependent and attenuated resting calcium-dependent abscisic acid induction of stomatal closure and abscisic acid-induced enhancement of calcium sensitivities of S-type anion and inward-rectifying $\mathrm{K}^{+}$channels in Arabidopsis guard cells. Plant J. 2009, 59, 207-220. [CrossRef]

218. Murata, Y.; Mori, I.C.; Munemasa, S. Diverse Stomatal Signaling and the Signal Integration Mechanism. Annu. Rev. Plant Biol. 2015, 66, 369-392. [CrossRef]

219. Farnese, F.S.; Menezes-Silva, P.E.; Gusman, G.S.; Oliveira, J.A. When Bad Guys Become Good Ones: The Key Role of Reactive Oxygen Species and Nitric Oxide in the Plant Responses to Abiotic Stress. Front. Plant Sci. 2016, 7, 471. [CrossRef]

220. Kollist, H.; Jossier, M.; Laanemets, K.; Thomine, S. Anion channels in plant cells. FEBS J. 2011, 278, 4277-4292. [CrossRef]

221. Assmann, S.M.; Jegla, T. Guard cell sensory systems: Recent insights on stomatal responses to light, abscisic acid, and $\mathrm{CO}_{2}$. Curr. Opin. Plant Biol. 2016, 33, 157-167. [CrossRef]

222. Jezek, M.; Blatt, M.R. The Membrane Transport System of the Guard Cell and Its Integration for Stomatal Dynamics. Plant Physiol. 2017, 174, 487-519. [CrossRef] 